\title{
LANDSCAPE-SCALE DISTURBANCES AND CHANGES IN BIRD COMMUNITIES OF BOREAL MIXED-WOOD FORESTS
}

\author{
Pierre Drapeau, ${ }^{1}$ Alain Leduc, ${ }^{1}$ Jean-Franço isGiroux, ${ }^{1}$ Jean-Pierre L. Savard, ${ }^{2}$ Yves Bergeron, ${ }^{1}$ \\ AND William L. Vickery ${ }^{1}$ \\ ${ }^{1}$ Groupe de recherche en écologie forestière interuniversitaire (GREFi), Département des sciences biologiques, \\ Université du Québec à Montréal, C. P. 8888, Succursale Centre-Ville, Montréal, Québec, Canada H3C $3 P 8$ \\ ${ }^{2}$ Canadian Wildlife Service, Québec region, 1141 route de l'Église, C. P. 10100, Ste-Foy, Québec, Canada G1V $4 H 5$
}

\begin{abstract}
Bird community response to both landscape-scale and local (forest types) changes in forest cover was studied in three boreal mixed-wood forest landscapes modified by different types of disturbances: (1) a pre-industrial landscape where human settlement, agriculture, and logging activities date back to the early 1930s, (2) an industrial timber managed forest, and (3) a forest dominated by natural disturbances. Birds were sampled at 459 sampling stations distributed among the three landscapes. Local habitat and landscape characteristics of the context surrounding each sampling station $(500-\mathrm{m}$ and $1-\mathrm{km}$ radius) were also computed. Bird communities were influenced by landscape-scale changes in forest cover. The higher proportion of early-successional habitats in both human-disturbed landscapes resulted in significantly higher abundance of early-successional bird species and generalists. The mean number of mature forest bird species was significantly lower in the industrial and pre-industrial landscapes than in the natural landscape. Landscape-scale conversion of mature forests from mixed-wood to deciduous cover in human-disturbed landscapes was the main cause of changes in mature forest bird communities. In these landscapes, the abundance of species associated with mixed and coniferous forest cover was lower, whereas species that preferred a deciduous cover were more abundant. Variation in bird community composition determined by the landscape context was as important as local habitat conditions, suggesting that predictions on the regional impact of forest management on songbirds with models solely based on local scale factors could be misleading. Patterns of bird species composition were related to several landscape composition variables (proportions of forest types), but not to configuration variables (e.g., interior habitat, amount of edge). Overall, our results indicated that the large-scale conversion of the southern portion of the boreal forest from a mixed to a deciduous cover may be one of the most important threats to the integrity of bird communities in these forest mosaics. Negative effects of changes in bird communities could be attenuated if current forestry practices are modified toward maintaining forest types (deciduous, mixed-wood, and coniferous) at levels similar to those observed under natural disturbances.
\end{abstract}

Key words: boreal bird communities; changes in forest cover; forest management implications; human disturbances; landscape context; local habitat conditions; long-term effects; mixed-wood forests.

\section{INTRODUCTION}

Large-scale natural disturbances, especially fires, have historically played a major role in determining the structure of boreal forest landscapes (Van Wagner 1978, Bergeron 1991, Johnson 1992, Anglestam 1996). In the last forty years, however, commercial timber management has become the prevalent perturbation in many parts of the boreal forest (Franklin and Forman 1987, Spies et al. 1994, Wallin et al. 1994, Enoksson et al. 1995, Anglestam 1996). Although forest management may show some similarities with natural disturbances (fire and insect outbreaks) to which organisms are adapted (Cameron 1953, Evans, 1964, 1966, Haila 1994, Haila et al. 1994, Hutto 1995), there are

Manuscript received 3 April 1998; revised 14 December 1998; accepted 11 March 1999; final version received 3 June 1999. important differences between these two types of disturbances (Spies and Cline 1988, Hutto 1995). Timber management can considerably modify the structure and composition of forest mosaics (Carleton and McLellan 1994, Spies et al. 1994, Edenius and Elmberg 1996, Gauthier et al. 1996, Bergeron and Harvey 1997). Cutting rates are generally shorter than natural fire cycles (Spies et al. 1994, Gauthier et al. 1996, Bergeron and Harvey 1997), and more severe in terms of live trees and coarse woody debris left following logging (Spies et al. 1994). Timber rotation length for even-aged silvicultural systems change the age-class distribution of forest types at the landscape scale (Spies et al. 1994, Hejl et al. 1995, Thompson et al. 1995). Mature and old-growth forest types become less common whereas the proportions of early-successional and young forest types increase (Hunter 1990, 1992, Hansen et al. 1991, Ripple et al. 1991, Cumming et al. 1994, Spies et al. 
1994, Hejl et al. 1995, Hagan et al. 1997). In boreal mixed-wood forests, short-return intervals between logging activities also change the tree-species composition of forest mosaics, usually with an increase in deciduous forest cover (Gauthier et al. 1996, Bergeron and Harvey 1997).

Such landscape-scale changes in forest cover raise concerns about how successfully managed forests can substitute for natural forests in offering suitable habitat conditions to maintain biodiversity (Ruggiero et al. 1991, Noss 1993, Hejl et al. 1995, Thompson et al. 1995). Large-scale changes to forests under management and their effects on birds have been documented in northern European boreal landscapes, (Helle and Järvinen 1986, Väisänen et al. 1986, Anglestam 1990, Edenius and Elmberg 1996). In North American boreal forests, however, few studies have addressed the issue of forest management and its impacts on birds at the landscape level (but see McGarigal and McComb 1995, Schmiegelow et al. 1997). Most research has been conducted at the stand or habitat level (Dobkin 1994, Freedman et al. 1994, Hejl et al. 1995, Thompson et al. 1995). Finally, concerns over large-scale changes of North American boreal forests and its effects on birds are also exacerbated by continental changes in populations trends of forest birds (Robbins et al. 1989b, Hagan and Johnston 1992, Askins 1993, Peterjohn et al. 1995).

In this paper, we examine how bird communities respond to landscape changes in forest cover that result from large-scale disturbances in a boreal mixed-wood forest in Abitibi, Quebec, Canada. We assess relationships between bird communities and forest mosaic characteristics following different types of disturbances in three contiguous landscapes: (1) a pre-industrial landscape where human settlement, logging activities, and agriculture date back to the early 1930s, (2) an industrial timber managed landscape characterized by recent commercial harvesting $(<20 \mathrm{yr})$ of the forest, and (3) a natural mixed-wood boreal forest landscape that is mainly affected by fire and insect outbreak disturbances. We focus on the consequences for bird communities of differences between landscape patterns created by human disturbances and natural disturbances. We ask the following questions: How different are bird community patterns between natural and human-induced forest mosaics? How are these patterns related to stand (forest types) and landscape characteristics (forest mosaics)? How can these differences be attenuated with alternative approaches to the management of forest landscapes?

\section{Methods}

\section{Study region}

The study was conducted in the Abitibi region, northwestern Quebec, Canada $\left(48^{\circ} \mathrm{N}, 79^{\circ} \mathrm{W}\right)$ (Fig. 1). Covering $350 \mathrm{~km}^{2}$, this area is part of the Northern Claybelt of Quebec and Ontario, a large physiographic region that originated from lacustrine deposits from the maximum post-Wisconsinian extension of postglacial lakes Barlow and Ojibway (Vincent and Hardy 1977). Hills with partially reworked or eroded till deposits are interspersed in lowlands covered by clays from postglacial lakes (Bergeron et al. 1982).

Located at the southern limit of the boreal forest, this area is characterized by a mixed-wood composition dominated by balsam fir (Abies balsamea), black spruce (Picea mariana), and paper birch (Betula papyrifera) with white spruce (Picea glauca) and trembling aspen (Populus tremuloides) as codominants (Rowe 1972). Under a natural disturbance regime, vegetation types vary in relation to surficial deposits and successional stages (Bergeron and Dubuc 1989). On clay, early successional stages are dominated by trembling aspen and intermediate stages by balsam fir, paper birch, and white spruce, whereas old stages are dominated by balsam fir and white cedar (Thuya occidentalis). On till, paper birch replaces trembling aspen in young stages whereas black spruce replaces white spruce in the intermediate stage. On bedrock, young and intermediate stages are dominated either by black spruce, jack pine (Pinus banksiana), or red pine (Pinus resinosa). Stands that have not been disturbed by fires for a long period are characterized by black spruce and white cedar. Finally, hydric sites are characterized by stands dominated by black spruce, white cedar, and larch (Larix laricina).

Human disturbances (agriculture and logging) have transformed the original forest cover in the middle and northern portions of the study area (Fig. 1). In the northern portion, human settlement and clearing parts of the forest for agriculture reached its maximum extent in the 1930s. In addition, the uncultivated portion of this pre-industrial landscape was modified by clearcutting and burning in the early 1940s. Since then, it has regenerated into second-growth contiguous forest tracts. The recent abandonment of cultivated fields has resulted in reforestation of some areas with early-successional habitats.

Intense clear-cutting of the middle portion of the study area (hereafter, referred to as the industrial landscape) took place in the late 1970 s following a spruce budworm (Choristoneura fumiferana) outbreak (Harvey and Bergeron 1989). Salvage cutting was conducted mechanically. Site preparation, planting and precommercial thinning are the silvicultural treatments used in this landscape. Unlogged forests in the industrial landscape are mainly composed of second-growth mature deciduous stands that originate from pre-industrial logging in the northern section. In the southern section of the industrial landscape, however, forest remnants are mostly made up of mature jack pine stands that originate from a fire in 1923 and old growth coniferous stands originating from a large-scale natural fire in 1760 (Dansereau and Bergeron 1993). The nat- 


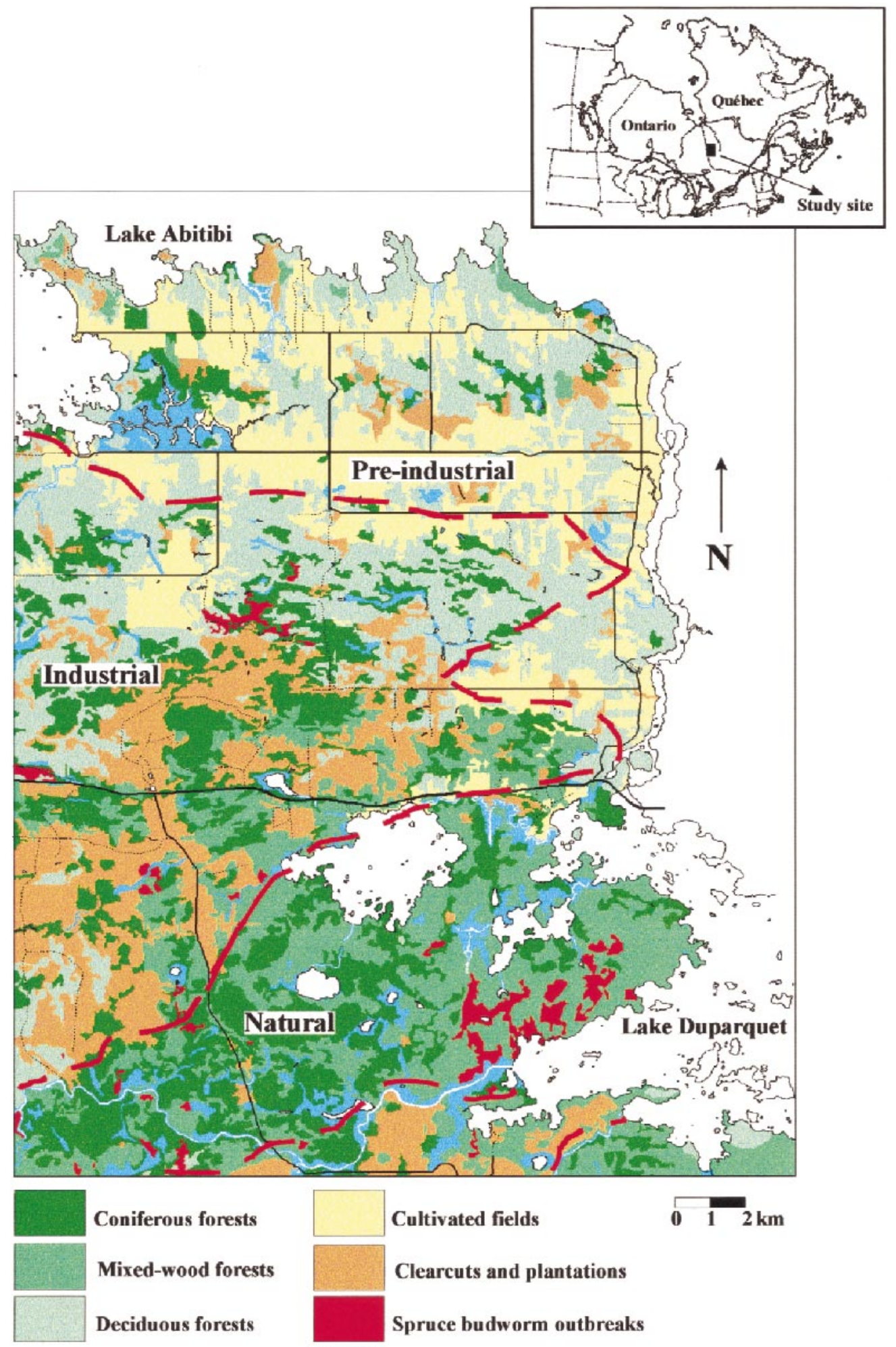

Wetlands - Alnus sp. shrub habitats

FIG. 1. Location of the study area in Abitibi, Québec and delineation of the pre-industrial, industrial, and natural landscapes. 
ural landscape is located in the southern portion, near Lake Duparquet (Fig. 1). This area has been affected mainly by natural disturbances such as fire and spruce budworm outbreaks (Dansereau and Bergeron 1993, Bergeron et al. 1995).

\section{Study design}

Landscape-scale patterns of bird community structure and composition were investigated over the entire forest mosaic, including all forest types rather than focusing on a single habitat type (e.g., mature forests). We took this approach because timber management affects all forest types (varying in age, structure, and composition) (Hejl et al. 1995, Thompson et al. 1995), and hence, may modify the dynamics of the entire landscape mosaic. Our approach also implicitly recognizes the contribution of adjacent forest types in the explanation of patterns that occur within each type across the forest mosaic (Askins and Philbrick 1987). It thus stresses the importance of turning our attention to the entire system with a landscape perspective (Wiens 1994, Freemark et al. 1995, Donovan et al. 1997).

Our sampling scheme did not rely on the conventional patch matrix conceptualization used in most habitat fragmentation studies. A simplified concept of forest patches and nonforest matrix was not appropriate for the landscapes studied. In both human-disturbed landscapes, remnant forests were aggregated and formed concentrations of large forest tracts rather than small patches widely dispersed and highly isolated (Fig. 1). Moreover, logging activities created heterogeneous mosaics of stands varying in age and in structure rather than a more homogeneous environment divided into forest fragments and nonforest matrix (sensu Addicott et al. 1987).

We used a stratified sampling design to cover the range of forest types in each landscape while accounting for the heterogeneity of forest mosaics (juxtaposition of forest types). We defined sixteen forest types based on canopy height (1-7 m, 7-12 m, >12 m), stand composition (deciduous, mixed, coniferous), and canopy closure $(<40 \%,>40 \%)$ using the forest cover maps (1:20 000) of the study area. In each landscape, sampling stations were grouped by line transects to maximize time spent sampling, minimize time traveling between sites, and consider interstand heterogeneity of forest mosaics. From four to six stations were located along line transects 1.2 to $2.5 \mathrm{~km}$ long. Line transects were separated by at least $1 \mathrm{~km}$. Distance between stations varied from $250 \mathrm{~m}$ to $400 \mathrm{~m}$, ensuring independence between stations (Bibby et al. 1992). Each station was within a relatively homogeneous forest type. Overall, 459 sampling stations along 100 line transects provided extensive coverage of the study area.

\section{Bird sampling}

The point count method was used to sample bird populations at each sampling station (Blondel et al.
1970, 1981, Ralph et al. 1995). Censuses were conducted during the breeding seasons of 1994 and 1995. Sampling was initiated at dawn and was conducted until 0900 (EST). Data on bird species' occurrence and abundance were recorded over an unlimited distance around each station. Sampling stations were visited twice during the breeding season, once in the first half and once in the second half of June. On each visit, birds (seen or heard) were recorded at 5-min intervals for a 20 -min period. The sampling sequence varied so that each station was visited once at dawn and once later in the morning to maximize detection probabilities of each species present.

A methodological study on the efficiency of the point count method in characterizing bird community species richness and composition at the scale of individual points (Drapeau et al. 1999) was used to establish the sampling procedure adopted in this study with regard to (1) the number of visits, (2) the spacing of visits during the breeding season, (3) the hourly periods appropriate for sampling, and (4) count duration. The maximum count on either one of the two visits was used to estimate the relative abundance of each species at each station.

Finally, bird censuses were conducted in comparable weather conditions, under clear and partly cloudy sky, and when wind speed generally did not exceed $8 \mathrm{~km}$ per hour. Counts were interrupted when wind speed exceeded $16 \mathrm{~km}$ per hour and when raining. Each sampling station was visited in only one of the two years.

\section{Local habitat variables}

Features of vegetation structure and composition were quantified at each sampling station from mid-July to mid-August. At each station, five $10 \times 10 \mathrm{~m}$ quadrats were located as follows: one at the center of the station and the others oriented in the cardinal compass directions $30 \mathrm{~m}$ from the center. In each quadrat, we measured and calculated 24 habitat variables (Table 1).

Vertical structure of the vegetation was subdivided into seven layers: $0-0.1 \mathrm{~m}, 0.1-0.5 \mathrm{~m}, 0.5-2.5 \mathrm{~m}, 2.5-$ $5 \mathrm{~m}, 5-10 \mathrm{~m}, 10-20 \mathrm{~m},>20 \mathrm{~m}$. For each layer, percent cover of vegetation was estimated using a semiquantitative scale $(0-1,1-5,5-25,25-50,50-75,>75 \%)$. The vertical structure of each sampling station was characterized by summing results over the five quadrats. The magnitude of horizontal heterogeneity of the vegetation within the stand was calculated for each vertical layer by comparing the percent cover among all possible pairs of quadrats with Sorensens' index of similarity (Legendre and Legendre 1983). High horizontal heterogeneity is obtained if all quadrats show different percent cover values while low values indicate small differences among quadrats. The number of standing dead trees (snags) and logs of $5-10 \mathrm{~cm} \mathrm{dbh}$ and $>10 \mathrm{~cm}$ dbh were recorded in each quadrat. The percent cover by conifers was recorded for the overstory $(>10 \mathrm{~m})$ and the understory $(2.5-10 \mathrm{~m})$ using the 
TABLE 1. Description of local habitat variables measured or calculated in the 459 sampling stations in Abitibi, Quebec, Canada, 1994-1995.

\begin{tabular}{|c|c|}
\hline Variable & Description \\
\hline FC1 & $\begin{array}{l}\text { Foliage cover of vegetation layer }>20 \\
m \text { in height }(\%)\end{array}$ \\
\hline $\mathrm{FC} 2$ & Foliage cover of vegetation layer $10-$ \\
\hline $\mathrm{FC} 3$ & $\begin{array}{l}\text { Foliage cover of vegetation layer } 5- \\
10 \mathrm{~m} \text { in height }(\%)\end{array}$ \\
\hline $\mathrm{UC} 1$ & $\begin{array}{l}\text { Understory cover of vegetation layer } \\
2.5-5 \mathrm{~m} \text { in height }(\%)\end{array}$ \\
\hline $\mathrm{UC2}$ & $\begin{array}{l}\text { Understory cover of vegetation layer } \\
0.5-2.5 \mathrm{~m} \text { in height }(\%)\end{array}$ \\
\hline HER & $\begin{array}{l}\text { Cover of herbaceous layer } 0-0.5 \mathrm{~m} \text { in } \\
\text { height }(\%)\end{array}$ \\
\hline MOS & Cover of mosses $(\%)$ \\
\hline HFC1 & $\begin{array}{l}\text { Horizontal heterogeneity of FC1 with- } \\
\text { in the stand } \dagger\end{array}$ \\
\hline $\mathrm{HFC} 2$ & $\begin{array}{l}\text { Horizontal heterogeneity of FC2 with- } \\
\text { in the stand }\end{array}$ \\
\hline $\mathrm{HFC} 3$ & $\begin{array}{l}\text { Horizontal heterogeneity of FC3 with- } \\
\text { in the stand }\end{array}$ \\
\hline HUC1 & $\begin{array}{l}\text { Horizontal heterogeneity of UC1 } \\
\text { within the stand }\end{array}$ \\
\hline HUC2 & $\begin{array}{l}\text { Horizontal heterogeneity of UC2 } \\
\text { within the stand }\end{array}$ \\
\hline HHER & $\begin{array}{l}\text { Horizontal heterogeneity of HER } \\
\text { within the stand }\end{array}$ \\
\hline HMOS & $\begin{array}{l}\text { Horizontal heterogeneity of MOS } \\
\text { within the stand }\end{array}$ \\
\hline SNG5 & $\begin{array}{l}\text { Number of standing dead trees } 5-10 \\
\mathrm{~cm} \mathrm{dbh}\end{array}$ \\
\hline SNG10 & $\begin{array}{l}\text { Number of standing dead trees }>10 \\
\mathrm{~cm} \mathrm{dbh}\end{array}$ \\
\hline LOG5 & Number of logs $5-10 \mathrm{~cm} \mathrm{dbh}$ \\
\hline LOG 10 & Number of logs $>10 \mathrm{~cm} \mathrm{dbh}$ \\
\hline CWDT & $\begin{array}{l}\text { Total number of coarse woody debris } \\
>10 \mathrm{~cm} \text { diameter }(\text { SNG10 }+ \\
\text { LOG10) }\end{array}$ \\
\hline $\mathrm{CON}$ & $\begin{array}{l}\text { Conifers in the stand (\% overstory } \\
{[>10 \mathrm{~m} \text { in height }]+\% \text { understory }} \\
[2.5-10 \mathrm{~m} \text { in height }])\end{array}$ \\
\hline $\mathrm{HCON}$ & $\begin{array}{l}\text { Horizontal heterogeneity of conifers } \\
\text { in the stand }\end{array}$ \\
\hline CONT & $\begin{array}{l}\text { Total importance of boreal vegetation } \\
\text { in the stand (CON }+ \text { PMOS) }\end{array}$ \\
\hline WAT & $\begin{array}{l}\text { Presence-absencof water bodies in } \\
\text { the station }\end{array}$ \\
\hline $\mathrm{MG}$ & $\begin{array}{l}\text { Moisture gradient (divided in three } \\
\text { classes: xeric, mesic, and hydric) }\end{array}$ \\
\hline
\end{tabular}

$\uparrow$ For each vegetation layer, heterogeneity values are calculated with Sorensens' index (Legendre and Legendre 1983), which measures the similarity of percent cover by vegetation layer among the five quadrats at each station.

same semiquantitative scale as above. General habitat features such as site moisture conditions (xeric, mesic, or hydric) and presence or absence of water bodies were also noted. Overall, local habitat variables were measured or calculated in 459 sampling stations with 2295 quadrats.

\section{Landscape context variables}

The landscape context around each sampling station was quantified using 42 variables (Table 2) derived from digitized vegetation maps $(1: 20000)$. We defined three nonforest habitat types (cultivated fields, humid shrublands, and residential areas) and 14 forest habitat types based on plant community (conifer, mixed, and hardwood), seral condition (grass/forbs, shrub/saplings, young forests, and late-successional forests) and canopy closure (open and closed).

The composition and configuration of the landscape surrounding each sampling station was measured in concentric circles of increasing radii of $500 \mathrm{~m}$ and 1 $\mathrm{km}$. Landscape composition was assessed by calculating within each circle the proportion of area occupied by each forest and nonforest habitat type. Landscape configuration was measured with four indices known to influence bird distribution. First, heterogeneity of forest mosaics surrounding each sampling point was assessed using a Shannon diversity index on the relative abundance of forest and nonforest habitats adjacent to each sampling station. Second, potential sensitivity to edge effects was calculated by superimposing a grid of cells (resolution level of $1 \mathrm{ha}$ ) on the vegetation maps with IDRISI (Eastman 1992). Within circles of $500 \mathrm{~m}$ and $1 \mathrm{~km}$ radii, we measured edge contrast among 1-ha cells using weights that represented greater contrast depending on the type of habitat interface. Weights ranged between 0 and 3 with the strongest difference between nonforest habitats and late-successional forest stands (cultivated field/mature forest). A weight of 2 was given to the contrast between early seral stages (clearcuts, plantations, shrubs/saplings, and abandoned fields) and mature forest stands ( $>12$ $\mathrm{m}$ at height) or nonforest habitats (cultivated fields) and young forest stands ( $<12 \mathrm{~m}$ at height). A weight of 1 was attributed to the following types of edges: nonforest/early seral, early seral/young forests, young forests/mature forests. Finally, a weight of 0 was attributed when mature forests were next to other mature forest stands. For each 1-ha cell we summed contrast with each of its eight neighboring cells. A maximum value of 24 could be obtained if, for example, a latesuccessional forest was surrounded by nonforest habitats. The proportion of mature forest 1-ha cells that showed high values (from 18 to 24 ) of potential sensitivity to edge effects was then used to compute the percentage of mature forests exposed to edge effects within each $500-\mathrm{m}$ and $1-\mathrm{km}$ circle. The 1 -ha level of resolution is close to the critical threshold of 50-100 $\mathrm{m}$ from the edge of forest fragments for which avian studies have shown that forest bird species are more sensitive to predation and parasitism pressures (Temple 1986, Temple and Cary 1988, Paton 1994, Askins 1995). The last two configuration indices were related to interior habitat (i.e., mature forests not in contact with open habitats). Within each concentric circle these indices were calculated by summing the 1-ha cells of mature forest with low values of potential sensitivity to edge effects (from 0 to 6) and dividing them by (1) the total area in each circle (proportion of interior habitat in the landscape) or (2) the area of mature forests 
TABLE 2. Variables used to quantify the composition and configuration of landscape contexts within $500 \mathrm{~m}$ and $1 \mathrm{~km}$ of the 459 sampling stations in Abitibi, Quebec, Canada, 1994-1995.

\begin{tabular}{|c|c|}
\hline Variable & Description \\
\hline CULT500 & Cultivated fields within $500 \mathrm{~m}$ of sampling station $(\%)$ \\
\hline RES500 & Landscape with residential areas within $500 \mathrm{~m}$ of sampling station (\%) \\
\hline YOD500 & Young $(<12 \mathrm{~m}$ in height) open $(<40 \%$ cover $)$ deciduous forest within $500 \mathrm{~m}$ of sampling station $(\%)$ \\
\hline YOC500 & Young $(<12 \mathrm{~m}$ in height) open $(<40 \%$ cover) coniferous forest within $500 \mathrm{~m}$ of sampling station $(\%)$ \\
\hline YCD500 & Young $(<12 \mathrm{~m}$ in height) closed $(>40 \%$ cover) deciduous forest within $500 \mathrm{~m}$ of sampling station $(\%)$ \\
\hline CLCT500 & Total clearcuts within $500 \mathrm{~m}$ of sampling station $(\% ;$ YCD500 + YOD500 + CLC500) \\
\hline SHR500 & Early-seral habitats dominated by shrubs within $500 \mathrm{~m}$ of sampling station $(\%)$ \\
\hline PLT500 & Plantations within $500 \mathrm{~m}$ of sampling station $(\%)$ \\
\hline MOD500 & Mature $(>12 \mathrm{~m}$ in height) open $(<40 \%$ cover $)$ deciduous forest within $500 \mathrm{~m}$ of sampling station $(\%)$ \\
\hline MOM500 & Mature $(>12 \mathrm{~m}$ in height) open $(<40 \%$ cover $)$ mixed-wood forest within $500 \mathrm{~m}$ of sampling station $(\%)$ \\
\hline MOC500 & Mature $(>12 \mathrm{~m}$ in height) open $(<40 \%$ cover $)$ coniferous forest within $500 \mathrm{~m}$ of sampling station $(\%)$ \\
\hline ALD1KM & Humid shrublands dominated by Alnus spp. within $1 \mathrm{~km}$ of sampling station (\%) \\
\hline RES1KM & Landscape with residential areas within $1 \mathrm{~km}$ of sampling station (\%) \\
\hline YOD1KM & Young $(<12 \mathrm{~m}$ in height $)$ open $(<40 \%$ cover $)$ deciduous forest within $1 \mathrm{~km}$ of sampling station $(\%)$ \\
\hline YOC1KM & Young $(<12 \mathrm{~m}$ in height) open $(<40 \%$ cover $)$ coniferous forest within $1 \mathrm{~km}$ of sampling station $(\%)$ \\
\hline YCD1KM & Young $(<12 \mathrm{~m}$ in height) closed $(>40 \%$ cover $)$ deciduous forest within $1 \mathrm{~km}$ of sampling station $(\%)$ \\
\hline YCC1KM & Young $(<12 \mathrm{~m}$ in height) closed $(>40 \%$ cover $)$ coniferous forest within $1 \mathrm{~km}$ of sampling station $(\%)$ \\
\hline CLC1KM & Recent clearcuts within $1 \mathrm{~km}$ of sampling station (\%) \\
\hline CLCT1KM & Total clearcuts within $1 \mathrm{~km}$ of sampling station (\%; YCD1KM + YOD1KM + CLC1KM) \\
\hline SHR1KM & Early-seral habitats dominated by shrubs within $1 \mathrm{~km}$ of sampling station (\%) \\
\hline PLT1KM & Plantations within $1 \mathrm{~km}$ of sampling station (\%) \\
\hline MOD1KM & Mature $(>12 \mathrm{~m}$ in height) open $(<40 \%$ cover $)$ deciduous forest within $1 \mathrm{~km}$ of sampling station $(\%)$ \\
\hline MOM1KM & Mature $(>12 \mathrm{~m}$ in height) open $(<40 \%$ cover $)$ mixed-wood forest within $1 \mathrm{~km}$ of sampling station $(\%)$ \\
\hline MOC1KM & Mature $(>12 \mathrm{~m}$ in height) open $(<40 \%$ cover $)$ coniferous forest within $1 \mathrm{~km}$ of sampling station $(\%)$ \\
\hline EDGE1KM & Mature forest exposed to edge effect within $1 \mathrm{~km}$ of sampling station $(\%)$ \\
\hline COREF1KM & Mature forest that corresponds to core habitat within $1 \mathrm{~km}$ of sampling station $(\%)$ \\
\hline COREL1KM & Landscape that corresponds to core habitat within $1 \mathrm{~km}$ of sampling station $(\%)$ \\
\hline
\end{tabular}

$\dagger$ Measures of habitat heterogeneity, core habitat, and edge effects are specified in Methods.

in each circle (proportion of interior habitat in mature forests).

\section{Overall landscape patterns}

Patchiness and heterogeneity for entire landscapes were assessed with FRAGSTATS (McGarigal and Marks 1995). Interior habitat (percentage of core area) and potential sensitivity to edge effects (percentage of late-successional forest exposed to edges) were calculated using a grid cell approach IDRISI (Eastman 1992) with a local operator that slides along each landscape unit (1-ha grid cell) and considers as neighbors the eight landscape units contiguous to the measured unit. Edge contrasts among 1-ha cells were computed using the same weights as the ones used in the landscape context analysis (see Methods: Landscape context variables). For each landscape, the proportion of mature forest stands that showed high values of potential sensitivity to edge effects (from 18 to 24 ) provided a measure of the importance of edges while the proportion of mature forest stands with low values of potential sensitivity to edge effects (from 0 to 6 ) provided a measure of the importance of interior habitat.

\section{Data analyses}

Measures of species diversity were assessed for each landscape at three levels: sampling station (alpha diversity), between sampling stations (beta diversity), and over the entire sample set (gamma diversity). Variations in alpha diversity were measured by calculating mean species richness of birds detected at individual sampling stations. Beta diversity corresponded to the species turnover among sampling stations. It was estimated by calculating the gradient length occupied by 
the sampling stations of each landscape on the first axis of a detrended correspondence analysis (DCA) (Hill 1979) of the species data matrix for the entire sample set. DCA produces a nonlinear rescaling of the ordination axes of a species data matrix that provides a reliable estimate of species turnover (Cramer and Hytteborn 1987, Eilerstsen et al. 1990). Gamma diversity was estimated using Heltshe and Forrester's (1983) jacknife estimator to control for unequal sample size among landscapes.

Many studies in fragmented habitats of North American temperate forests have suggested that the impoverishment of species assemblages is nonrandom, but rather linked to the life history characteristics of the species involved (Whitcomb et al. 1981, Ambuel and Temple 1983, Freemark and Merriam 1986, Askins and Philbrick 1987, Blake and Karr 1987, Blake 1991). Hence, instead of strictly focusing on whole community parameters, these studies have conducted more detailed analyses on groups of species that are potentially affected by habitat fragmentation. Bird community structure was therefore assessed by comparing groups of species. We classified each species by its migratory status based on information contained in Whitcomb et al. (1981), Freemark and Merriam (1986), Robbins et al. (1989a, b) and McGarigal and McComb (1995). We also determined habitat association by examining habitat use of each species across the gradient of forest types covered in our study. Species were classified into the following categories: (1) early-successional habitats, (2) young forests, (3) mature forests, and (4) generalists.

Comparisons among landscapes for alpha, beta, gamma, mean number of individuals per station, and species grouped by migratory status were conducted using one-way ANOVAs. Comparisons for species grouped by habitat use were conducted using two-way ANOVAs with the three landscapes (pre-industrial, industrial, and natural) and four forest types (deciduous, mixeddeciduous, mixed-coniferous, and coniferous). Local scale changes in tree species composition of forest stands following human or natural disturbances cumulatively modified the proportions of forest types in each landscape. This resulted in covariance between vegetation cover at local and landscape scales in the three landscapes under study. While we made efforts in our study design to correct for uneven representation of all forest types across the three landscapes, the sample set among landscapes was nevertheless unbalanced for some forest types. Two-way ANOVAs were used to control a posteriori the effect of local habitat canopy cover (forest types) and allow us to separate local scale from landscape scale differences or similarities in species groups parameters across landscapes. Furthermore, for three of the four habitat-use species groups, we further controlled local effects by analyzing data for the subset of sampling stations that corresponded to early-successional habitats $(n=127)$, young forests $(n$
$=111)$, and mature forests $(n=221)$. Post hoc comparisons of means among landscapes were performed using Tukey's tests (Sokal and Rohlf 1981). All ANOVAs were computed using SAS (SAS Institute 1988).

Canonical correspondence analysis (CCA; ter Braak 1986, 1990) was used: (1) to compare the species composition of bird communities among the three landscapes, (2) to determine the combinations of variables both for local and landscape scales that were most strongly related to bird community composition, and (3) to measure the relative contribution of local and landscape scales in variation of bird community composition. A correspondence analysis (CA) was first conducted on the bird species data matrix to provide a representation of the position of the sampling stations on the first two axes of a dispersion diagram. To facilitate comparisons among landscapes, $67 \%$ concentration ellipses were overlaid on the dispersion diagram. The $67 \%$ criteria was chosen to include all sampling stations for which coordinates on the first two axes were within one unit of standard deviation from the centroid of each landscape, thus providing a view of the mean size of each cluster of sampling stations. Two canonical ordinations, each of them constrained by one set of explanatory variables (local scale or landscape scale), were then performed to determine which were the most important variables at each scale.

Finally, the partial constrained option of CCA (ter Braak 1988) with the CANOCO program of ter Braak $(1988,1990)$ was used to measure the relative contribution of local and landscape scales in variation of bird community composition. Two canonical ordinations, each of them constrained by one set of explanatory variables were performed to get a measure of the total importance for the species data of (1) the local habitat variables and (2) the landscape context variables. Two other partial CCA that constrained the species matrix by either one of the two sets of explanatory variables after removing the effect of the other set were also conducted. The approach developed by Borcard et al. (1992) was used to partial out the amount of variation (sum of canonical eigenvalues) in the bird species data that is related to these two sets of explanatory variables.

\section{RESULTS}

\section{Overall landscape patterns}

The proportion of mature forests ( $>12 \mathrm{~m}$ high) was nearly twice as much in the natural landscape than in the pre-industrial and industrial landscapes (Table 3). Differences between the two human-disturbed landscapes were mainly related to the proportion of young forest stands $(<12 \mathrm{~m}$ high $)$ and plantations, which reached $32 \%$ in the industrial landscape and only $14 \%$ in the pre-industrial landscape (Table 3).

In mature forests, the proportion of mixed-wood habitat was highest in the natural landscape, followed by the industrial and pre-industrial landscapes (Table 4). 
TABLE 3. Area occupied by land-use types based on GIS analyses of digitized forest maps in pre-industrial, industrial, and natural landscapes of a boreal mixed-wood forest in Abitibi, Quebec, Canada.

\begin{tabular}{|c|c|c|c|c|c|c|c|c|}
\hline \multirow[b]{2}{*}{ Land use } & \multicolumn{2}{|c|}{ Pre-industrial } & \multicolumn{2}{|c|}{ Industrial } & \multicolumn{2}{|c|}{ Natural } & \multicolumn{2}{|c|}{ Entire study area } \\
\hline & Area (ha) & $\%$ & Area (ha) & $\%$ & Area (ha) & $\%$ & Area (ha) & $\%$ \\
\hline Wetlands & 484 & 3.98 & 312 & 2.22 & 594 & 6.71 & 1390 & 3.97 \\
\hline Shrublands & 79 & 0.65 & 272 & 1.94 & 296 & 3.34 & 647 & 1.84 \\
\hline Rocky outcrops & 59 & 0.48 & 174 & 1.24 & 135 & 1.52 & 368 & 1.05 \\
\hline Human settlement & 59 & 0.48 & 29 & 0.21 & 14 & 0.15 & 102 & 0.29 \\
\hline Cultivated fields & 4443 & 36.56 & 388 & 2.77 & 0 & 0.00 & 4831 & 13.79 \\
\hline Abandoned fields & 351 & 2.88 & 86 & 0.61 & 0 & 0.00 & 437 & 1.24 \\
\hline Spruce budworm outbreaks $\dagger$ & 0 & 0.00 & 177 & 1.26 & 1381 & 15.57 & 1558 & 4.40 \\
\hline Clearcuts & 794 & 6.53 & 2917 & 20.82 & 56 & 0.63 & 3767 & 10.25 \\
\hline Plantations & 228 & 1.87 & 1380 & 9.85 & 8 & 0.09 & 1616 & 4.61 \\
\hline Young forests ( $<12 \mathrm{~m}$ in height) & 1448 & 71.91 & 3077 & 21.96 & 1381 & 15.57 & 5906 & 16.87 \\
\hline Mature forests ( $>12 \mathrm{~m}$ in height) & 4205 & 34.61 & 5375 & 38.36 & 6364 & 71.90 & 15944 & 45.54 \\
\hline Total & 12150 & & 14010 & & 8851 & & 35011 & \\
\hline
\end{tabular}

$\dagger$ Young forests in the natural landscape originated from Spruce budworm outbreaks in the 1970s. Area and percentages for these two land types are similar and thus are not additive, being mutually inclusive in the natural landscape.

Correspondingly, the proportion of deciduous forest cover increased from the natural to the industrial and reached it highest value in the pre-industrial landscape. Mature trembling aspen stands dominated the pre-industrial landscape.

Spatial analyses of the three landscapes indicated a gradual increase of patchiness of forest mosaics from natural to the pre-industrial landscapes (Table 5). Mean patch size of all mature forest types was similar in the pre-industrial and industrial landscapes, but one-third as large as in the natural landscape. Habitat diversity was higher in both human-disturbed landscapes than in the natural landscape and the percentage of interior forest habitat reached its highest value in the natural landscape (Table 5). Nevertheless, the percentage of interior forest habitat remained important in both human-disturbed landscapes. Despite a gradual increase from the natural to the pre-industrial landscape, potential sensitivity of the forest cover to edge effects was weak in all landscapes (Table 5). Low values of percentage of edge effects and high values of interior forest habitat in both human-dominated landscapes indicated that transformations of the forest cover resulted in a spatial arrangement of remaining mature forest stands that was aggregated and contiguous rather than highly isolated (Fig. 1).

\section{Bird community structure and species groups patterns}

Of the 118 bird species recorded over the two visits, 84 were associated with forest habitats. Community structure and species composition analyses were conducted on this set of species (see Appendix for species list). Alpha diversity did not differ significantly among the three landscapes (Table 6). The total number of individuals detected per sampling station did not differ between human-disturbed landscapes but was significantly lower in the natural landscape. Beta diversity reached its peak in the pre-industrial landscape, reached its lowest value in the natural landscape and was intermediate in the industrial landscape (Table 6). Gamma diversity estimates were similar in the humandominated landscapes but lower in the natural landscape (Table 6).

Neotropical migrants represented from $52 \%$ to $55 \%$ of the 84 forest species detected. Short-distance migrants and residents made up respectively $32 \%$ to $36 \%$ and $8 \%$ to $10 \%$ of the detections in the avifauna in the three landscapes. Species grouped by migratory status (mean species richness and mean number of individuals per station) did not show significant differences among landscapes. The mean species richness of Neotropical

TABLE 4. Area of deciduous, mixed-wood, and coniferous forest types in mature forests ( $>12 \mathrm{~m}$ in height) based on GIS analyses of digitized forest maps of pre-industrial, industrial, and natural landscapes of a boreal mixed-wood forest in Abitibi, Quebec, Canada.

\begin{tabular}{|c|c|c|c|c|c|c|c|c|}
\hline \multirow[b]{2}{*}{ Forest type } & \multicolumn{2}{|c|}{ Pre-industrial } & \multicolumn{2}{|c|}{ Industrial } & \multicolumn{2}{|c|}{ Natural } & \multicolumn{2}{|c|}{ Entire study area } \\
\hline & Area (ha) & $\%$ & Area (ha) & $\%$ & Area (ha) & $\%$ & Area (ha) & $\%$ \\
\hline Deciduous & 2803 & 66.66 & 2014 & 37.39 & 1051 & 16.46 & 5868 & 36.75 \\
\hline Mixed-wood & 695 & 16.53 & 2142 & 39.91 & 4151 & 65.23 & 6988 & 43.83 \\
\hline Coniferous & 707 & 16.81 & 1219 & 22.70 & 1162 & 18.31 & 3088 & 19.42 \\
\hline Total & 4205 & & 5375 & & 6364 & & 15944 & \\
\hline
\end{tabular}


TABLE 5. Landscape configuration statistics of forest mosaics calculated with FRAGSTATS and IDRISI programs in the pre-industrial, industrial, and natural landscapes of a boreal mixed-wood forest in Abitibi, Quebec, Canada.

\begin{tabular}{|c|c|c|c|}
\hline Configuration variable & Pre-industrial & Industrial & Natural \\
\hline Total area (ha), $\mathrm{TA} \dagger$ & 12150 & 14010 & 8851 \\
\hline Mean patch size of forests (ha), MPS & 23.74 & 23.47 & 74.09 \\
\hline Simpson's index of habitat diversity, SIDI & 0.77 & 0.85 & 0.69 \\
\hline Potential sensitivity to edges effects $\S(\%)$ & 25.63 & 15.56 & 6.69 \\
\hline Importance of interior habitat $\S(\%)$ & 48.14 & 48.79 & 67.70 \\
\hline
\end{tabular}

$\dagger$ Acronyms correspond to those used in FRAGSTATS (McGarigal and Marks 1995).

tForests $(>12 \mathrm{~m})$ refer to closed canopy of deciduous, mixed-wood, or coniferous cover.

$\S$ Indices measured with IDRISI (Eastman 1992) as specified in Methods.

migrants, short-distance migrants, and residents was similar among landscapes. Although significant, differences among landscapes for mean number of individuals of short-distance and Neotropical migrants were slight (Fig. 2).

The mean number of mature forest species and individuals diminished significantly from the natural to the pre-industrial landscape, with the industrial landscape between these two extremes (Fig. 2). The mean number of individuals and mean species richness associated with young forests were higher in the preindustrial landscape than in the other two landscapes. Mean numbers of species and individuals associated with early successional forests were significantly lower in the natural landscape than in either human-disturbed landscape (Fig. 2). Finally, generalists were significantly more abundant in the pre-industrial landscape than in the other two landscapes, both in terms of mean numbers of species and individuals (Fig. 2).

\section{Overall patterns of bird community species composition}

Forty-two percent of the variation in species composition was summarized by the first two axes of the correspondence analysis (CA) of the bird species data matrix. Several features of the variation in species composition of bird communities characterized each landscape as shown by the concentration ellipses (Fig. 3). The size of the ellipses on the first two axes indicates that variation in bird community composition was greater in human-disturbed landscapes than in the natural landscape (Fig. 3). The position of the ellipses in the diagram, in particular along the first axis, illustrates from left to right a gradual transition from natural to industrial and then to pre-industrial landscapes. Preindustrial and natural landscapes occupy extreme portions on the gradient, emphasizing the dissimilarity of bird communities of these two landscapes (Fig. 3). Bird communities of the industrial landscape have compositional characteristics that were intermediate between the pre-industrial and the natural landscape. Finally, while the composition of bird communities varied among landscapes, the amount of overlap shown by the ellipses indicates a definite similarity in bird communities among the three landscapes.

The CA species ordination diagram shows on the first axis a trend from bird species associated with early-successional shrub habitats on the right, through species associated with young forests in the central region to mature forests species on the left (Fig. 4). Logging and abandoned cultivated fields create new early-successional shrub habitats that favor the presence of species such as Lincoln's Sparrow, Alder Flycatcher, and Common Yellowthroat as well as young forest stands that are used by Nashville Warblers, Mourning Warblers, and Chestnut-sided Warblers. The second axis segregates mature deciduous forest species (such as Veery, Least Flycatcher, Ovenbird, Rose-breasted

TABLE 6. Descriptive statistics and results of one-way ANOVAs on comparisons of bird community structure parameters among the three landscapes and four forest types (deciduous, mixed-deciduous, mixed-coniferous, and coniferous) of a boreal mixed-wood forest in Abitibi, Quebec.

\begin{tabular}{|c|c|c|c|c|c|c|c|c|c|}
\hline \multirow[b]{2}{*}{ Community parameter } & \multicolumn{2}{|c|}{$\begin{array}{l}\text { Preindustrial } \\
\quad n=164\end{array}$} & \multicolumn{2}{|c|}{$\begin{array}{c}\text { Industrial } \\
n=169\end{array}$} & \multicolumn{2}{|c|}{$\begin{array}{c}\text { Natural } \\
n=126\end{array}$} & \multirow[b]{2}{*}{$F$} & \multirow[b]{2}{*}{$P$} & \multirow{2}{*}{$\begin{array}{c}\text { Tukey's } \\
\text { HSD }\end{array}$} \\
\hline & Mean & SD & Mean & SD & Mean & SD & & & \\
\hline Alpha diversity $\dagger$ & 20.13 & 5.17 & 20.11 & 4.40 & 19.28 & 4.59 & 1.44 & 0.239 & $\mathrm{~A}, \mathrm{~A}, \mathrm{~A}$ \\
\hline Individuals per station & 32.62 & 11.46 & 31.19 & 7.69 & 27.99 & 7.17 & 9.44 & 0.001 & $\mathrm{~A}, \mathrm{~A}, \mathrm{~B}$ \\
\hline Beta diversity: & 2.61 & & 2.29 & & 1.88 & & & & \\
\hline Gamma diversity & 88 & 3.05 & 89 & 2.75 & 70 & 1.71 & & & \\
\hline
\end{tabular}

Note: Significant differences within each landscape are indicated by different letters in the last column.

$\uparrow$ Alpha diversity refers to the mean number of species detected in a sampling station.

† $\$$ ta diversity represents the turnover of species among sampling stations in each landscape. Details on how it is measured are specified in Methods.

§ Gamma diversity refers to total species richness for the entire landscape. It is estimated following a jackknife procedure (Heltshe and Forrester 1983), to control for differences in sample size among landscapes. 

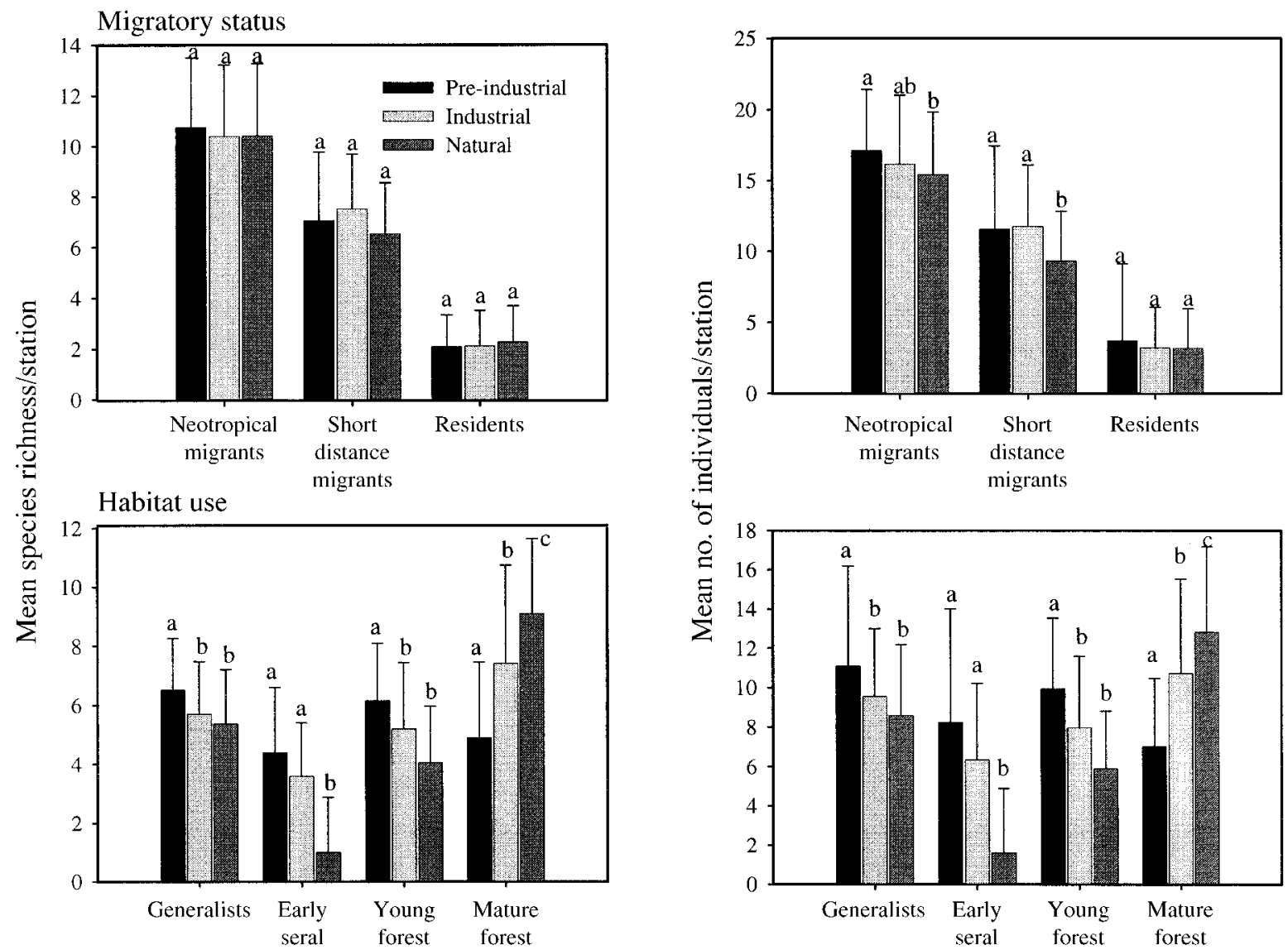

FIG. 2. Mean species richness and mean number of individuals per sampling station for species grouped by migratory status and habitat use in the three landscapes (pre-industrial, industrial, and natural). Species grouped by migratory status were compared by landscape with one-way ANOVAs. Comparisons for species grouped by habitat use were conducted using two-way ANOVAs with the three landscapes and four forest types (deciduous, mixed-deciduous, mixed-coniferous, and coniferous). Means and standard deviations ( $+1 \mathrm{SD})$ of species richness and number of individuals for these three categories were estimated on a subset of 127 sampling stations for early-seral species, 111 for species in young forests, and 221 stations for species in mature forests. Significant differences within each landscape are indicated by different letters.

Grosbeak) at the upper end of the diagram, and coniferous forest birds such as Ruby-crowned Kinglet, Golden-crowned Kinglet, Yellow-bellied Flycatcher, and Red-breasted Nuthatch at the lower end (Fig. 4).

Constrained ordinations of the species matrix by local habitat variables and landscape context variables showed a strong fit between the constrained axes and these sets of explanatory variables (see canonical correlation coefficients, Table 7). CCA of the species matrix by local habitat variables indicated that the first canonical axis was mainly correlated with foliage cover (FC1 to FC3) of tree layers, whereas the importance of coniferous woody cover was the strongest environmental correlate on the second canonical axis (Table 7). The landscape context CCA shows that the proportion of shrub habitats (SHR500), the proportion of cultivated fields (CULT500), and the proportion of plantations (PLT500) were the most important landscape context variables correlated to the first canonical axis (Table 7). The strongest correlate of the second axis, the proportion of closed deciduous forest cover within $1 \mathrm{~km}$ of the sampling stations (MCD1KM), highlights the importance for bird communities of the conversion of mature forests from coniferous and mixed-wood in the natural landscape to deciduous in the pre-industrial landscape (Table 7). Finally, none of the landscape configuration variables were strongly correlated with the first two axes of the CCA (Table 7).

\section{Relative contribution of local habitat and landscape context variables}

Partial constrained ordinations using CCA allowed us to partition the variance of the species data matrix and to determine the relative contribution of local and landscape context variables (Table 8 ). Overall, $25 \%$ of the variation in the bird species data matrix was explained by these sets of explanatory variables. Of this explained variation, $38 \%$ was uniquely related to local habitat variables and $29 \%$ to landscape context variables. An important proportion of the explained vari- 


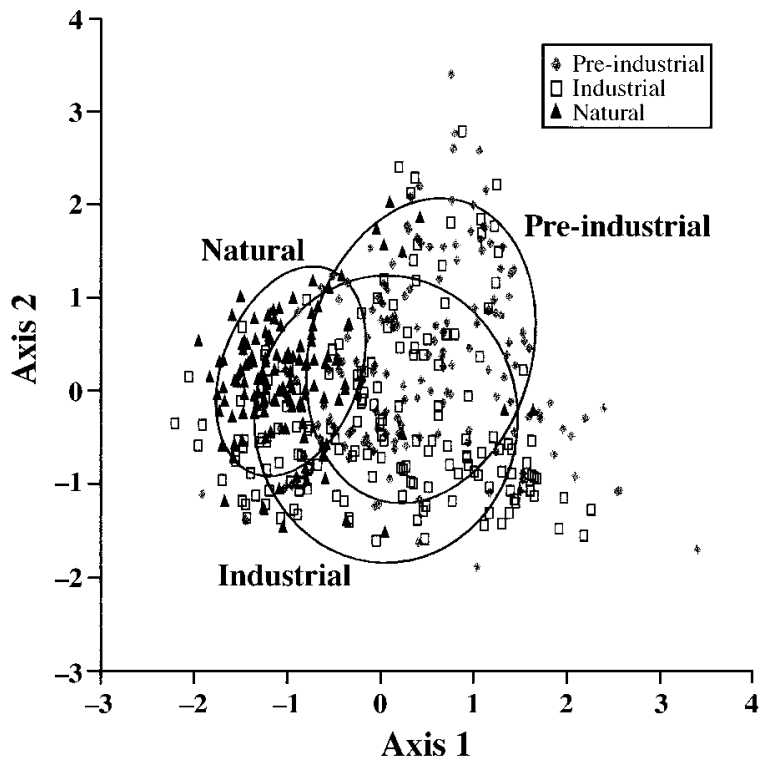

FIG. 3. Ordination of the 459 sampling stations obtained from a correspondence analysis (CA) of the species composition of bird communities across the gradient of forest habitats in the three landscapes. For each landscape, $67 \%$ concentration ellipses are overlaid on the diagram.

ation (33\%) was simultaneously related to both sets of variables.

\section{Bird community composition of mature forests}

To explore further differences in the composition of bird communities among landscapes, we conducted a more detailed analysis on a subset of 221 sampling stations covering all types of mature forests. The CA species ordination diagram and the overlay of ellipses representing the position of $67 \%$ of sampling stations for each landscape provide a more detailed view of the position of mature forest birds in the three landscapes (Fig. 5). The spatial arrangement of the three landscapes and the width of the ellipses for mature forests is consistent with patterns observed in the ordination of the total sample set (Figs. 3, 4). Bird communities of mature forests were more variable in pre-industrial and industrial landscapes than in the natural landscape (Fig. 5). Examination of the position of the ellipses with regards to bird species location indicates that the pre-industrial landscape was strongly characterized by mature deciduous forest bird communities as shown by species such as Least Flycatcher and Veery at the right end of the first axis (Fig. 5). Bird community composition of mature forests in the industrial landscape lies between these two extremes, including both boreal and deciduous community types. Mature forests in the natural landscape were characterized by a more homogenous bird community composition strongly associated with the coniferous component of the boreal mixed-wood forest with species such as the Rubycrowned Kinglet, Golden-crowned Kinglet, Red- breasted Nuthatch, and Magnolia Warbler that occupy the left portion of the diagram (Fig. 5).

These patterns were also obvious when we examined the frequency of occurrence of individual species among the three landscapes (Table 9). Many species associated with boreal mixed-woods and coniferous forest cover showed a significantly lower frequency of occurrence in the industrial and pre-industrial landscapes (Blackburnian Warbler, Golden-crowned Kinglet, Red-breasted Nuthatch, Bay-breasted Warbler, Black-throated Blue Warbler, Black-throated Green Warbler, Dark-eyed Junco, Ruby-crowned Kinglet, and Magnolia Warbler). In contrast, the frequency of occurrence of species that have affinities for deciduous forest cover were significantly higher in mature forests of the pre-industrial landscape (Veery and Least Flycatcher).

\section{Discussion}

\section{Overall patterns}

Total bird diversity index (gamma diversity) in forest mosaics of the three landscapes reached their highest values in human-disturbed landscapes. Similar patterns were obtained for beta diversity whereas no significant difference was observed at the scale of alpha diversity. Blondel (1995) discussed the links among these three scales, emphasizing that gamma diversity in a landscape is determined by: (1) how species interact in the same environment (alpha diversity) and (2) how they respond to heterogeneity along environmental gradients (beta diversity). Our results suggest that increases in total bird diversity (gamma diversity) in forest mosaics of both human-disturbed landscapes are mainly associated with the increased proportion of early-successional habitats created by logging (industrial landscape) and the abandonment of cultivated fields (preindustrial landscape). Increases in the regional importance of early-successional habitats provided ecological opportunities for additional species that were less abundant in small forest openings (such as openings created by spruce budworm outbreaks) of the natural landscape (Fig. 2). This increased the length of the bird community gradient and, hence, the species turnover rate (beta diversity) in both human-disturbed landscapes. Human disturbances in the composition and configuration of these forest mosaics did not, however, result in a "crowding effect" of birds (Whitcomb et al. 1981, Lemhkuhl et al. 1991, Schmiegelow et al. 1997), so species diversity did not increase at the local scale (alpha diversity).

When we examined the structure of bird communities with respect to migratory strategy of songbirds, no difference in the number of species or the overall abundance of Neotropical migrants and residents were observed between the natural and human-disturbed landscapes. These two groups of species are usually recognized as potentially sensitive to forest fragmentation 


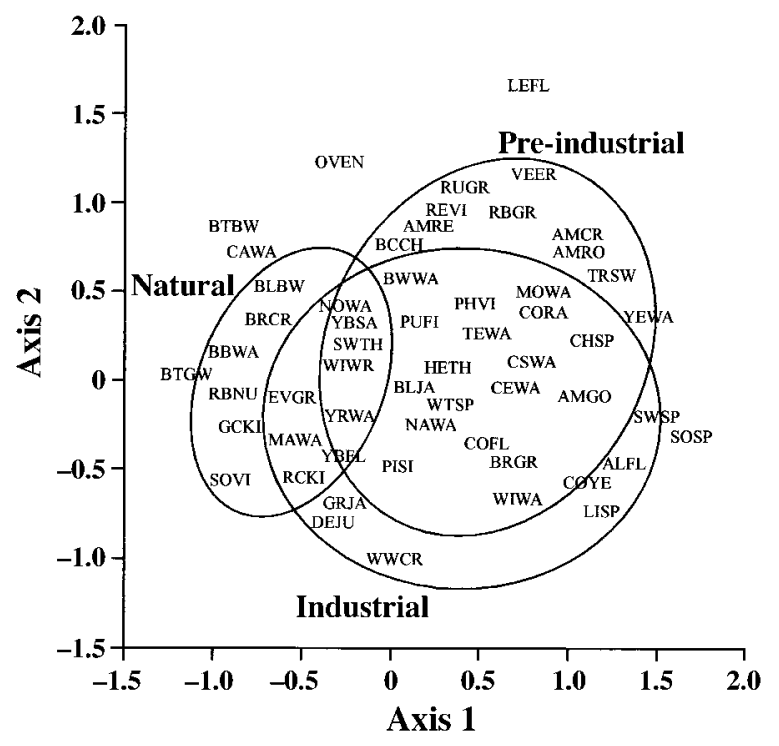

FIG. 4. Ordination of the bird species on the first two axes of the correspondence analysis of bird community data. For each landscape, $67 \%$ concentration ellipses are presented. Abbreviations are: ALFL, Alder Flycatcher; AMCR, American Crow; AMGO, American Goldfinch; AMRE, American Redstart; AMRO, American Robin; BBWA, Bay-breasted Warbler; BCCH, Black-capped Chickadee; BLBW, Blackburnian Warbler; BLJA, Blue Jay; BRCR, Brown Creeper; BRGR, Bronzed Grackle; BTBW, Black-throated Blue Warbler; BTGW, Black-throated Green Warbler; BWWA, Black-andwhite Warbler; GRJA, Gray Jay; CAWA, Canada Warbler; CEWA, Cedar Waxwing; CHSP, Chipping Sparrow; COFL, Common Flicker; CORA, Common Raven; COYE, Common Yellowthroat; CSWA, Chestnut-sided Warbler; DEJU, Darkeyed Junco; EVGR, Evening Grosbeak; GCKI, Goldencrowned Kinglet; HETR, Hermit Thrush; LEFL, Least Flycatcher; LISP, Lincoln Sparrow; MAWA, Magnolia Warbler; MOWA, Mourning Warbler; NAWA, Nashville Warbler; NOWA, Northern Waterthrush; OVEN, Ovenbird; PHVI, Philadelphia Vireo; PISI, Pine Siskin; PUFI, Purple Finch; RBGR, Rose-breasted Grosbeak; RBNU, Red-breasted Nuthatch; RCKI, Ruby-crowned Kinglet; REVI, Red-Eyed Vireo; RUGR, Ruffed Grouse; SOSP, Song Sparrow; SOVI, Solitary Vireo; SWSP, Swamp Sparrow; SWTH, Swainson's Thrush; TEWA, Tennessee Warbler; TRSW, Tree Swallow; VEER, Veery; WIWA, Wilson's Warbler; WIWR, Winter Wren; WTSP, White-throated Sparrow; WWCR, White-winged Crossbill; YBFL, Yellow-bellied Flycatcher; YBSA, Yellowbellied Sapsucker; YEWA, Yellow Warbler; YRWA, Yellowrumped Warbler.

(Robbins et al. 1989a, Askins et al. 1990, Askins 1995, Enoksson et al. 1995, Edenius and Elmberg 1996). Our results lend support to Hejl et al. (1995) comments on the difficulty of using migratory status guilds as indicators of silvicultural treatments.

Abundance trends, however, did differ among habitat-use species groups. The abundance of bird species that occupy early-successional habitats increased in both human-disturbed landscapes. This result is consistent with increases in the overall proportion of earlysuccessional habitats (clearcuts and abandoned fields) in both human-disturbed landscapes. It supports pre- dictions that early-successional species will increase in managed forest landscapes (Raphael et al. 1988, Hagan et al. 1997).

Bird communities in early-successional habitats originating from human disturbances were also different than in forest openings that resulted from natural disturbances such as spruce budworm outbreaks. Species composition of bird communities in stations sampled in spruce budworm outbreaks of the natural landscape was closer to that of mature forests than to earlysuccessional habitats of human-disturbed landscapes (all stations were located at the right end of first axis on Fig. 3). Although it is likely that these differences were influenced in part by the type of disturbance and its effects on vegetation structure (complete removal of vegetation in clearcuts vs. gaps in the canopy, increases of snag density, and understory development caused by outbreaks), our results indicate that the size of the opening of the forest cover was an important factor. Large-scale openings of the forest cover in both human-disturbed landscapes increased the availability of open habitats and provided numerous opportunities for populations of early-successional species whereas spruce budworm outbreaks created smaller-scale openings (Fig. 1).

Generalist species were significantly more abundant in the pre-industrial landscape than in either the industrial and natural landscapes. American Crow and Common Raven reached their peak of detection in the pre-industrial landscape where a high proportion (37\%) of the land was cultivated (Table 3). Andrén (1992) also found that corvid densities were higher in landscapes with a mixture of farmland and forest than in landscapes dominated either by farmland or forest. Finally, contrary to other studies conducted in managed forests landscapes (Thompson et al. 1992, Hannon 1993, Schmiegelow et al. 1997), potential parasitism pressure was nonexistent due to the near absence (two records in two years) of the Brown-headed Cowbird in our study area.

The mean number of mature forest bird species was significantly lower in the industrial and pre-industrial landscapes compared with the natural landscape. Important changes in bird species composition of mature forests also occurred across the three landscapes (Fig. 5). Boreal species became significantly less abundant from the natural to the pre-industrial landscape (Table 9). This downward trend was in part consistent with the loss of mature forests that characterizes humandisturbed landscapes (Andrén 1994, Hagan et al. 1997). Conversion of mature forests from mixed-wood to deciduous across the three landscapes was, however, the main factor for the differences in abundance patterns of mature forest birds across landscapes. Decreases in proportion of mixed-wood stands from the natural, to the industrial and the pre-industrial landscapes (Table 4) was consistent with both the reduction in mean number of mature forest species (Fig. 2) and changes in 
TABLE 7. Correlations of significant $(P<0.01)$ local habitat variables and landscape context variables on the first two axes of canonical correspondence analyses of the bird species matrix constrained by each set of explanatory variables.

\begin{tabular}{|c|c|c|c|}
\hline \multicolumn{2}{|r|}{ Variable } & Axis 1 & Axis 2 \\
\hline \multicolumn{2}{|c|}{ Canonical correlations of axes: species matrix constrained by local habitat matrix } & 0.83 & 0.75 \\
\hline \multicolumn{2}{|c|}{ Variation $(\%)$ of the species-local habitat matrices accounted for by each axis } & 43.10 & 28.20 \\
\hline \multicolumn{2}{|c|}{ Canonical correlations of axes: species matrix constrained by landscape context matrix } & 0.76 & 0.71 \\
\hline \multicolumn{2}{|c|}{ Variation $(\%)$ of the species-landscape context matrices accounted for by each axis } & 39.30 & 24.30 \\
\hline \multicolumn{4}{|c|}{ Local habitat variables } \\
\hline $\mathrm{FC} 2$ & Foliage cover of vegetation layer $10-20 \mathrm{~m}$ in height $(\%)$ & -0.81 & 0.46 \\
\hline FC3 & Foliage cover of vegetation layer $5-10 \mathrm{~m}$ in height $(\%)$ & -0.72 & 0.20 \\
\hline FC1 & Foliage cover of vegetation layer $>20 \mathrm{~m}$ in height $(\%)$ & -0.66 & 0.42 \\
\hline LOG10 & Number of $\operatorname{logs}>10 \mathrm{~cm} \mathrm{dbh}$ & -0.59 & -0.08 \\
\hline $\mathrm{HCON}$ & Horizontal heterogeneity of conifers in the stand & -0.37 & -0.18 \\
\hline MOS & Cover of mosses $(\%)$ & -0.25 & -0.72 \\
\hline $\mathrm{CON}$ & Conifers in the stand $(\%)$ & -0.16 & -0.84 \\
\hline HER & Cover of herbaceous layer $0-0.5 \mathrm{~m}$ in height $(\%)$ & 0.55 & 0.55 \\
\hline \multicolumn{4}{|c|}{ Landscape context variables } \\
\hline MCC1KM & Mature $(>12 \mathrm{~m}$ in height) closed $(>40 \%$ cover $)$ coniferous forest within $1 \mathrm{~km}(\%)$ & -0.22 & -0.30 \\
\hline YCC500 & $\begin{array}{l}\text { Young }(<12 \mathrm{~m} \text { in height) closed }(>40 \% \text { cover }) \text { coniferous forest within } 500 \mathrm{~m} \text { of } \\
\text { sampling station }(\%)\end{array}$ & -0.20 & -0.23 \\
\hline MOC500 & Mature $(>12 \mathrm{~m}$ in height $)$ open $(<40 \%$ cover $)$ coniferous forest within $500 \mathrm{~m}(\%)$ & -0.14 & 0.07 \\
\hline MOD500 & Mature $(>12 \mathrm{~m}$ in height) open $(<40 \%$ cover $)$ deciduous forest within $500 \mathrm{~m}(\%)$ & 0.06 & 0.51 \\
\hline MCD1KM & Mature ( $>12 \mathrm{~m}$ in height) closed ( $>40 \%$ cover) deciduous forest within $1 \mathrm{~km}(\%)$ & 0.22 & 0.85 \\
\hline RES500 & Landscape with residential areas within $500 \mathrm{~m} \mathrm{( \% )}$ & 0.24 & -0.11 \\
\hline SHR500 & Early seral habitats dominated by shrubs within $500 \mathrm{~m}(\%)$ & 0.49 & 0.20 \\
\hline PLT500 & Plantations within $500 \mathrm{~m}(\%)$ & 0.51 & -0.64 \\
\hline CULT500 & Cultivated fields within $500 \mathrm{~m}(\%)$ & 0.66 & 0.39 \\
\hline
\end{tabular}

species composition of mature forest bird communities (see axis 2 of Fig. 4 and Table 7).

\section{Relative contribution of local habitat and landscape context variables}

In recent years it has become a common view among ecologists that the landscape context surrounding habitats influences animal population patterns and processes as much as local habitat conditions (Askins et al. 1987, Wiens 1989, 1994, Andrén 1994, Blondel 1995, Freemark et al. 1995, Thompson et al. 1995, Findlay and Houlahan 1997). Inferences on how landscape structure affects wildlife patterns, however, have often been based on relationships derived at the local scale (patch characteristics vs. species richness or abundance) thus providing indirect evidence and no quantification on the influence of landscape structure on such patterns (McGarigal and McComb 1995).

Two-way ANOVA comparisons of species groups across landscapes provided insight into the importance of the landscape scale in bird community patterns. By statistically controlling the effect of local forest type in these analyses, we have ruled out the possibility that landscape-scale differences in broad community structure parameters merely represented a surrogate of localscale changes in forest types. Hence, for example, the

TABLE 8. Relative contribution of local and landscape scale sets of variables in the explanation of the variation of bird community data in three landscapes of a boreal mixed-wood forest in Abitibi, Quebec. Partitioning of the variation in bird species data matrix is similar to that of Borcard et al. (1992) developed with CANOCO.

\begin{tabular}{|c|c|c|c|c|}
\hline Step $\dagger$ & Description of the analysis & $\begin{array}{l}\text { Sum } \\
\text { of all } \\
\text { eigen- } \\
\text { values }\end{array}$ & $\begin{array}{l}\text { Measure of } \\
\text { percentage of } \\
\text { the variation } t\end{array}$ & $\begin{array}{l}\text { Percent- } \\
\text { age of } \\
\text { the } \\
\text { variation }\end{array}$ \\
\hline 1 & CA of the species matrix & 2.121 & & \\
\hline 2 & CCA of the species matrix constrained by local habitat variables & 0.369 & $0.369 / 2.121$ & 17.4 \\
\hline 3 & CCA of the species matrix constrained by landscape context variables & 0.347 & $0.347 / 2.121$ & 16.4 \\
\hline 4 & $\begin{array}{l}\text { CCA constrained by local habitat variables after removing the effect of land- } \\
\text { scape context variables }\end{array}$ & 0.172 & $0.172 / 2.121$ & 8.1 \\
\hline 5 & $\begin{array}{l}\text { CCA constrained by landscape context variables after removing the effect of } \\
\text { local habitat variables }\end{array}$ & 0.150 & $0.150 / 2.121$ & 7.1 \\
\hline \multirow{4}{*}{\multicolumn{2}{|c|}{$\begin{array}{l}\text { Total variation accounted by both sets of variables: (steps } 2+5 \text { or steps } 3+4) \\
\text { Relative contribution of local habitat variables to the explained variation } \\
\text { Relative contribution of landscape context variables to the explained variation } \\
\text { Shared contribution of both sets of variables to the explained variation }\end{array}$}} & 0.519 & $0.519 / 2.121$ & 24.5 \\
\hline & & & $0.172 / 0.519$ & 33.1 \\
\hline & & & $0.150 / 0.519$ & 28.9 \\
\hline & & & $0.197 / 0.519$ & 38.0 \\
\hline
\end{tabular}




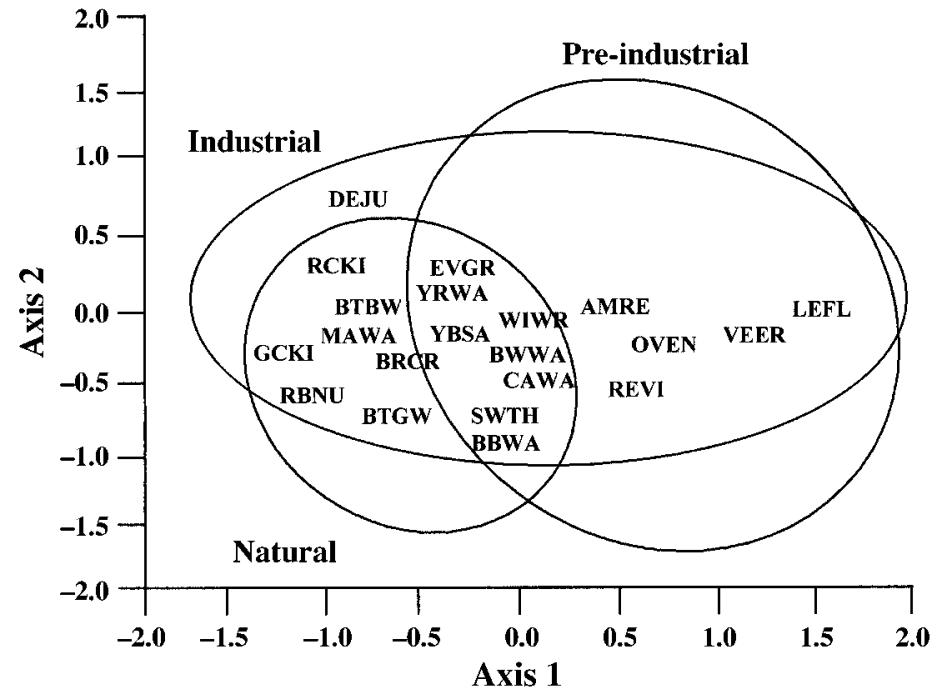

FIG. 5. Ordination of the bird species on the first two axes of the correspondence analysis of bird community data for the subset of 221 stations sampled in mature forest stands. For each landscape, $67 \%$ concentration ellipses are presented. Only species significantly associated to each axis are presented. Abbreviations are: AMRE, American Redstart; BBWA, Baybreasted Warbler; BRCR, Brown Creeper; BTBW, Black-throated Blue Warbler; BTGW, Black-throated Green Warbler; BWWA, Blackand-white Warbler; CAWA, Canada Warbler; DEJU, Dark-eyed Junco; EVGR, Evening Grosbeak; GCKI, Golden-crowned Kinglet; LEFL, Least FLycatcher; MAWA, Magnolia Warbler; OVEN, Ovenbird; RBNU, Red-breasted Nuthatch; RCKI, Ruby-crowned Kinglet; REVI, Red-Eyed Vireo; SWTH, Swainson's Thrush; VEER, Veery; WIWR, Winter Wren; YBSA, Yellow-bellied Sapsucker; YRWA, Yellowrumped Warbler. statistically significant difference in the mean number of mature forest birds among the three landscapes after removing the local effect of tree species composition of forest types indicates that mature forest birds are truly under the influence of a landscape-scale change in the forest mosaic.

The analysis of the species composition of bird communities however, provided a more detailed quantification of how bird assemblages are associated with landscape-scale characteristics. The surrounding land- scape significantly influenced the composition of bird communities (Table 7). The partitioning of the variation in bird community data between local and landscape scale sets of explanatory variables with CANOCO showed that the contribution of landscape context variables was equivalent to that of local habitat variables (Table 8). This supports the notion that patterns and processes in ecology are influenced at multiple scales (Gutzwiller and Anderson 1987, Wiens et al. 1993, Donovan et al. 1997). Furthermore, the important con-

TABLE 9. Frequency of occurrence of mature forest bird species and results of $G$ tests comparing their distribution in the three landscapes in Abitibi, Quebec.

\begin{tabular}{lcccc}
\hline \hline \multicolumn{1}{c}{ Species } & $\begin{array}{c}\text { Pre- } \\
\text { industrial } \\
(n=62)\end{array}$ & $\begin{array}{c}\text { Industrial } \\
(n=66)\end{array}$ & $\begin{array}{c}\text { Natural } \\
(n=93)\end{array}$ & $G$ values \\
\hline Blackburnian Warbler & 9 & 17 & 56 & $24.93^{* * *}$ \\
Golden-crowned Kinglet & 12 & 35 & 66 & $22.51^{* * *}$ \\
Veery & 44 & 26 & 23 & $18.11^{* * *}$ \\
Black-throated Blue Warbler & 13 & 15 & 46 & $12.11^{* *}$ \\
Red-breasted Nuthatch & 10 & 24 & 44 & $11.56^{* *}$ \\
Dark-eyed Junco & 2 & 13 & 18 & $10.41^{* *}$ \\
Magnolia Warbler & 24 & 52 & 59 & $9.03^{*}$ \\
Bay-breasted Warbler & 7 & 15 & 32 & $8.93^{*}$ \\
Least Flycatcher & 25 & 21 & 16 & $7.78^{*}$ \\
Black-throated Green Warbler & 11 & 19 & 39 & $7.49^{*}$ \\
Ruby-crowned Kinglet & 20 & 37 & 58 & $7.39^{*}$ \\
Yellow-rumped Warbler & 17 & 32 & 51 & $7.00^{*}$ \\
Swainson's Thrush & 34 & 50 & 83 & $6.08^{*}$ \\
Evening Grosbeak & 11 & 18 & 36 & $5.94^{\mathrm{NS}}$ \\
Canada Warbler & 14 & 15 & 37 & $5.20^{\mathrm{NS}}$ \\
Brown Creeper & 6 & 13 & 23 & $4.95^{\mathrm{NS}}$ \\
Yellow-bellied Sapsucker & 26 & 45 & 58 & $4.46^{\mathrm{NS}}$ \\
Winter Wren & 39 & 54 & 87 & $4.44^{\mathrm{NS}}$ \\
Black-and-white Warbler & 40 & 43 & 43 & $3.35^{\mathrm{NS}}$ \\
Ovenbird & 57 & 50 & 78 & $1.00^{\mathrm{NS}}$ \\
American Redstart & 49 & 47 & 73 & $0.34^{\mathrm{NS}}$ \\
Mmotes: & & & & \\
\end{tabular}

Notes: Only species for which loadings on the CA ordination strongly contributed to structure of the first two axes of the ordination diagram are presented. Species are listed from most significant differences in occurrence among landscapes to least different. Mature forests include deciduous, mixed, and coniferous stands $>12 \mathrm{~m}$ in height with closed and open canopy.

$* P<0.05 ; * * P<0: 01 ; * * * P<0.001 ;$ NS, not significant. 
tribution of the landscape context alone (once the effect of local habitat conditions is removed), in the explanation of bird community data suggests that forest landscape mosaics appear to be more than the sum of forest types and are in their own right an important component for songbirds. Hence, predictions of the regional consequences of forest management on wildlife based solely on local scale models are likely to be misleading. Conversely, limiting the analysis of wildlife patterns to single landscape scale factors may also be misleading because landscape scale effects may be confounded with unmeasured local scale factors (see McGarigal and McComb 1995). We thus consider that to test the hypothesis that landscape structure exerts an independent influence on songbirds patterns of distribution we have to control for the effect of variation in local habitat characteristics. This can be done a priori with an experimental design that controls the variation in local scale factors (see Freemark and Merriam 1986, Donovan et al. 1997). However, controlling simultaneously for local multiple habitat factors in real landscapes may not always be feasible in ecological studies. Another approach that can be used is to control local habitat factors a posteriori at the step of data analysis by removing their effects. Techniques such as partial correlations coefficients, partial linear regressions (Pearson 1993), path analysis (Sokal and Rohlf 1981), partial log-linear models (Whittaker 1984), or partial constrained ordinations can be used to remove the effect of local habitat factors. We consider that this latter approach offers a great potential for incorporating multiple scale factors into wildlife-habitat modeling given the inherent problems of setting up experimental designs at landscape scales. Until recently, this approach has rarely been used in wildlife-habitat models, even for those that have incorporated explanatory variables measured over multiple scales. This may in part be related to the fact that researchers were originally more concerned with the development of models that best explain the variation of the response variable (Freemark and Merriam 1986, Askins et al. 1987, Robbins et al. 1989a) than with the issue of the relative contribution of spatial scales (through sets of explanatory variables) in organisms distribution and ecology.

Finally, the use of partial ordinations not only allowed us to determine the fraction of the variation that was unique to each set but we also found that part of the explained variation was simultaneously related to variables at these two scales. This portion of the explained variation thus provides a measure of the amount of communality (sensu Whittaker 1984) between the two sets. Hence, along nested scales of investigation the contribution of environmental conditions (at local and landscape levels) to the explanation of bird community patterns cannot be conceptualized as a simple additive model where sets of variables from each scale are completely independent to one another. Local and landscape-scale factors that are significantly associated with bird community patterns are nonmutually exclusive (see Quinn and Dunham 1983) and may indeed covary in real landscapes.

\section{Contribution of landscape configuration and composition variables}

Patterns of bird community composition were related to several landscape composition variables but not to configuration variables (interior habitat, amount of edges). Variation in bird community composition was primarily associated with increases in the proportion of stands in early successional stage from the natural to the pre-industrial landscape (first axis of CANOCO; Fig. 4, Table 7). Hence, changes in age distribution of forest types within forest mosaics are important for bird communities. Changes in species composition of mature forest bird communities (second axis of CANOCO; Fig. 4, Table 7) were also more closely related to differences in proportions of adjacent forest types (deciduous, mixed, coniferous) than to differences in configuration (size, isolation, increase of edges) of these remnant forests.

The lack of relationships between bird patterns and landscape configuration may partly reflect the nature of habitat modifications induced by human-disturbances in our study area. As previously mentioned, mature forests in both human-disturbed landscapes form aggregates and result in concentrations of large tracts rather than small patches widely dispersed and highly isolated. They were created following an aggregated cutting process that minimizes forest-clearcut edges and mitigates the decline of interior-forest habitat (Wallin et al. 1994). This may explain the lack of correlation of songbird community patterns with variables such as the amount of edge or the percentage of interior habitat.

These results are nevertheless suggestive of more general trends that may occur elsewhere in managed boreal forests. Other studies conducted in industrial landscapes also failed to show strong relationships between bird distribution patterns and landscape configuration attributes (Rosenberg and Raphael 1986, Hejl 1992). Lemhkuhl et al. (1991) observed increases of bird abundance in old growth Douglas-fir stands of the Washington Cascade Range as the percentage of clearcuts increased in the landscape. They interpreted this pattern as a "crowding" effect resulting from the movement of individuals from logged areas to adjacent suitable habitat. McGarigal and McComb (1995) found weak relationships between species' abundance and landscape configuration attributes of mature forests in forest landscapes of the Oregon Coast Range. In a recent experimental study, Schmiegelow et al. (1997) concluded that the magnitude of fragmentation effects on songbirds observed in their study was small.

Differences in the strength of relationships between forest bird species' abundance and landscape configuration and composition variables in managed boreal forests may be attributed to several factors. First, man- 
aged and unmanaged boreal forest landscapes are often juxtaposed in space (Spies et al. 1994, McGarigal and McComb 1995, Edenius and Elmberg 1996, Schmiegelow et al. 1997; this study). On a regional scale, the forest cover rarely falls below the $30 \%$ threshold where configuration attributes (patch size, patch/edge contrast) become important explanatory variables (see Andrén 1994). Hence, configuration effects on birds at the scale of managed forests may be dampened by large blocks of unmanaged forest (Spies et al. 1994, McGarigal and McComb 1995, Schmiegelow et al. 1997). Second, in contrast to agricultural forest landscapes of eastern deciduous forests, managed boreal forests are not sharply divided between simple forest and nonforest habitats. Boundaries among habitats are likely to be less sharp and less hostile to forest birds (Askins and Philbrick 1987, Rudnicky and Hunter 1993a) and edge-related effects on birds may be less severe (Rudnicky and Hunter 1993b, Darveau et al. 1997). Third, changes in composition of nearby habitats following logging may be far more critical for birds than changes in configuration of remnant mature forest patches. Changes in the proportion of forest types redefine the texture of landscape mosaics and mature forest habitats become part of a new heterogeneous mosaic of forest types that could, in turn, directly influence birds that occupy these remnant habitats (Wiens 1994). This may explain why landscape composition variables such as proportion of forest types are more often correlated to bird patterns than are landscape configuration attributes in our study and in other studies (McGarigal and McComb 1995). Finally, recent studies in the midwestern United States that focused on comparing agricultural forest landscapes for different levels of forest fragmentation (including highly fragmented landscapes) also showed that landscape composition attributes (i.e., proportions of forest cover in the surrounding landscape) were strongly associated with nesting success (Robinson et al. 1995, Donovan et al. 1997). Hence, greater attention should be paid to landscape-scale changes in forest cover and their impacts on forest birds in managed boreal forests.

\section{Long-term effects of forest management on boreal bird communities}

Recent studies suggesting that impacts of forestry practices on biodiversity should be measured at a landscape scale (Dobkin 1994, Freedman et al. 1994, Hejl et al. 1995, Thompson et al. 1995) also advocate looking at long-term impacts of forest management because changes in forest mosaics and on its wildlife do not usually occur during a short time frame. For instance, change in the age-class distribution of stands in forest mosaics due to short timber rotation length in managed forests has been identified as one important long-term effect of forest management on boreal forest ecosystems and their wildlife (Cumming et al. 1994, Spies et al. 1994, Wallin et al. 1994, Gauthier et al. 1996). In- creases in the proportion of early-successional habitats and decreases in mature and old-growth habitats influence landscape-scale patterns of wildlife populations and communities (Hansen et al. 1991, Spies et al. 1994, Hejl et al. 1995). Hence, the high regional abundance of bird species associated with early-successional habitats found in our industrial landscape could likely persist in managed forest landscapes. Likewise species' abundance of mature forest birds may also be maintained at lower levels if the proportions of mature and old-growth forests in managed forest landscapes is reduced in comparison with the ones in landscapes submitted to a natural disturbance regime (Hansen et al. 1991).

One difficulty in assessing long-term impacts of forest management in boreal forests is that most industrial logging dates back to the early 1950s (Carleton and McLellan 1994, Spies et al. 1994). Boreal landscapes have not undergone yet a complete rotation where the forest is at a steady state (unchanged proportions of forest types) and reaches a regulated condition (i.e., equal proportions of all age classes). However, based on the actual patterns that we found in our study area with boreal mixed-wood forests that were logged in the 1930 s and on predictions of the future state of currently managed forests, it is possible to foresee some longterm effects of forest management on songbird communities in Abitibi.

In the pre-industrial landscape our results clearly showed that the dominance of deciduous forest types in the forest mosaic translates into large-scale changes in the species composition of forest bird communities in comparison with those of the natural landscape. This high proportion of deciduous forest types may persist in this landscape because successional pathways towards mixed and coniferous forest types may be truncated. Logging in the 1930s almost completely eliminated coniferous tree species over large areas, inhibiting the invasion of softwood species (Galipeau et al. 1997). Burning then eliminated "advanced growth" seedlings of conifers. This combined effect greatly jeopardized the regeneration of coniferous species and offered numerous regrowth opportunities to deciduous species that regenerated from seeds or sucker shoots from the root system (Fowells 1965). The understory of current mature second-growth forests in our preindustrial landscape is thus lacking coniferous saplings and is mainly dominated by mountain maple (Acer spicatum) (P. Drapeau, unpublished data). Furthermore, these patterns are likely to be representative of the entire human settled portion of the Abitibi region given that this juxtaposition of human-disturbances occurred over a large portion of the region.

In cut-over areas that originate from industrial logging ( $<40 \mathrm{yr}$ ), impacts of industrial forestry practices on vegetation regeneration indicate that the proportion of deciduous forest cover in this landscape is also likely to be high when these forests reach commercial timber 
maturity (Harvey and Bergeron 1989, Carleton and McLellan 1994). Carleton and McLellan (1994) have showed that postfire stands mostly regenerated to coniferous forests and boreal mixed-woods whereas postlogged stands were almost entirely deciduous. They argued that the large-scale conversion from conifer to broadleaf forests that is currently underway in the boreal mixed-wood forest is in part related to impacts of forestry practices on vegetation regeneration. Because their study was conducted in northeastern Ontario, a region adjacent to our study area, similar patterns of forest regrowth are likely to apply to our study area.

Decreases in the proportions of mixed-wood and coniferous cover and increases in deciduous cover may also persist in managed forest landscapes because the timber rotation length is generally shorter (between 50 and 70 years) than current fire cycles $(>100 \mathrm{yr}$ ) (Bergeron 1991, Dansereau and Bergeron 1993, Gauthier et al. 1996, Bergeron and Harvey 1997). Projections of forest mosaic diversity based on a model of natural forest dynamics after fire in the Abitibi portion of the boreal mixed-wood forest indicate that managed landscapes will become dominated by deciduous forest types if current silviculture practices are maintained (Gauthier et al. 1996). Such changes in forest cover are likely to modify the composition of bird communities in managed forests towards patterns that will be more similar to those already detected in our pre-industrial landscape than to those that characterize the natural landscape.

Changes in tree-species composition of mature forests and its effects on bird communities have also been identified as one of the most important impact of modern forestry in Europe (Swenson and Anglestam 1993, Enoksson et al. 1995, Edenius and Elmberg 1996). This conversion was, however, from natural deciduous stands to large-scale artificially regenerated commercial coniferous species. In North America, Welsh (1987) discussed the increased dominance of deciduous forest types in boreal mixed-wood forests as a potential causal factor for changes in bird community composition observed at the stand scale. However, to our knowledge, our study is the first to quantify landscapescale changes of bird community composition in response to changes in the proportions of forest types of landscape mosaics.

\section{Management implications}

While forest management's main objective is to perpetuate forests, not to convert them to other land uses as with other human disturbances (Hejl et al. 1995), it may nevertheless in the long term alter the composition and structure of forest mosaics and hence biodiversity. In boreal mixed-wood forests, impacts of industrial logging on vegetation regeneration (Carleton and McLellan 1994) coupled with short timber rotations (Spies et al. 1994, Gauthier et al. 1996) should produce a greater proportion of deciduous forest cover than in unmanaged forests. We believe that this pattern will be prevalent in the next timber rotation, even though recent forestry practices such as careful logging have greatly improved conifer regeneration in softwood stands and are becoming the new silvicultural standards. These forestry practices have been in use only since the beginning of the 1990s. Therefore, changes in landscape patterns that are linked to these practices will lag behind changes induced by industrial forest management from the 1950s through the 1980s. For bird communities, this conversion of mature forests from mixed-wood to deciduous cover may jeopardize their ecological integrity, notably through collapses of regional populations of bird species associated with mixed and coniferous mature forests. Hence, even though forest management may show some similarities with natural disturbances (fire and insect outbreaks), under current forestry practices, it appears unlikely that managed forests can adequately substitute for natural forests in the boreal mixed-wood forest zone.

Changes in species composition of bird communities may be attenuated, however, provided that current forestry practices are modified in managed forest landscapes. Approaches that are based on patterns and processes of natural ecosystem dynamics have recently been proposed as new models of silviculture that can conciliate cost-effective wood production with maintenance of biodiversity (Bradshaw et al. 1994, Haila et al. 1994, Galindo-Leal and Bunnel 1995, Bergeron and Harvey 1997). In boreal mixed-wood forests, Bergeron and Harvey (1997) proposed combining several standlevel silvicultural treatments in order to favor the transition between forest types (deciduous, mixed-wood, coniferous) rather than the traditional cyclical rotation of similarly composed stands. At the landscape level, they urged forest managers to plan towards maintaining a proportion of deciduous, mixed-wood, and coniferous forest types that is close to the proportion found in natural forest mosaics of the boreal mixed-wood forest. Guidelines on proportions of stand types to maintain for different rotation periods could be set with landscape-scale models of forest dynamics under natural disturbance regimes (Gauthier et al. 1996).

For boreal mixed-wood forest birds, maintenance of forest types (deciduous, mixed-wood, and coniferous) at levels similar to those observed under natural conditions is likely to be a good regional conservation strategy in managed forests. Preservation of large tracts of natural boreal mixed woods adjacent to managed forest landscapes, such as our natural landscape, may also contribute to maintenance of boreal mixed-wood bird communities since they may act as population sources for remnant forest patches in managed landscapes (Askins 1995, Robinson et al. 1995). Bird populations could be maintained in these patches through a "rescue effect" (Brown and Kodric-Brown 1977) during the critical period of forest regeneration. Furthermore, these two strategies are conceptually linked 
to the view that conservation of bird populations should be set within a hierarchical approach in which local scale decisions are made in light of the regional and landscape context (Freemark et al. 1995, Thompson et al. 1995, Welsh and Venier 1996, Donovan et al. 1997). Landscape-scale models of forest dynamics coupled with empirical models of the response of birds to modifications in the proportions of forest types could be helpful in setting thresholds for preserving the integrity of bird communities of mixed-wood boreal forests.

\section{ACKNOWLEDGMENTS}

This research was supported by the Quebec Ministry of Environment, the Quebec Ministry of Natural Resources, Wildlife Habitat Canada, the Canadian Wildlife Service (Quebec region), and the National Center for Excellence on Sustainable Forest Management. We thank Réjean Deschênes, Serge Rhéaume, Simon Bérubé, Steve Hamel, and Simon Béliveau for their assistance during field work. Marc-André Villard made helpful suggestions on previous versions of the manuscript.

\section{Literature Cited}

Addicott, J. F., J. M. Aho, M. F. Antolin, D. K. Padilla, J. S Richardson, and D. A. Soluk. 1987. Ecological neighborhoods: scaling environmental patterns. Oikos 49:340-346.

Ambuel, B., and S. A. Temple. 1983. Area-dependent changes in the bird communities and vegetation of southern Wisconsin forests. Ecology 64:1057-1068.

Andrén, H. 1992. Corvid density and nest predation in relation to forest fragmentation: a landscape perspective. Ecology 73:794-804.

Andrén, H. 1994. Effects of habitat fragmentation on birds and mammals in landscapes with different proportions of suitable habitat: a review. Oikos 71:355-366.

Anglestam, P. A. 1990. Factors determining the composition and persistence of local woodpecker assemblages in taiga forest in Sweden - ase for landscape ecological studies. Pages 147-164 in A. Carlson and G. Aulén, editors. Conservation and management of woodpecker populations. Swedish University of Agricultural Science, Department of Wildlife Ecology, Uppsala, Report 17. Uppsala, Sweden.

Anglestam, P. A. 1996. The ghost of forest past-natural disturbance regimes as a basis for reconstruction of biologically diverse forests in Europe. Pages 287-337 in R. M. DeGraaf and R. I. Miller, editors. Conservation of faunal diversity in forested landscapes. Chapman and Hall, New York, New York, USA.

Askins, R. A. 1993. Population trends in grassland, shrubland and forest birds in eastern North America. Current Ornithology 11:1-34.

Askins, R. A. 1995. Hostile landscapes and the decline of migratory songbirds. Science 267:1956-1957.

Askins, R. A., J. F. Lynch, and R. Greenberg. 1990. Population declines in migratory birds in eastern North America. Current Ornithology 7:1-56.

Askins, R. A., and M. J. Philbrick. 1987. Effect of changes in regional forest abundance on the decline and recovery of a forest bird community. Wilson Bulletin 99:7-21.

Askins, R. A., M. J. Philbrick, and D. S. Sugeno. 1987. Relationship between the regional abundance of forest and the composition of forest bird communities. Biological Conservation 39:129-152.

Bergeron, Y. 1991. The influence of island and mainland lakeshore landscapes on the boreal forest fire regimes. Ecology 72:1980-1992.

Bergeron, Y., C. Camiré, A. Bouchard, and P. Gangloff. 1982. Analyse et classification des sols pour une étude écologique intégrée d'un secteur de l'Abitibi, Québec. Géographie Physique et Quaternaire 36:291-305.

Bergeron, Y., and M. Dubuc. 1989. Succession in the southern part of the Canadian boreal forest. Vegetatio 79:51-63.

Bergeron, Y., and B. D. Harvey. 1997. Basing silviculture on natural ecosystem dynamics: an approach applied to the southern boreal mixed-wood forest of Québec. Forest Ecology and Management 92:235-242.

Bergeron, Y., A. Leduc, H. Morin, and C. Joyal. 1995. Balsam fir mortality following the last spruce budworm outbreak in northwestern Quebec. Canadian Journal of Forest Research 25:1375-1384.

Bibby, C. J., N. D. Burgess, and D. A. Hill. 1992. Bird census techniques. Academic Press, San Diego, California, USA.

Blake, J. G. 1991. Nested subsets and the distribution of birds on isolated woodlots. Conservation Biology 5:58-66.

Blake, J. G., and J. R. Karr. 1987. Breeding birds of isolated woodlots: area and habitat relationships. Ecology 68:17241734.

Blondel, J. 1995. Biogéographie, approche écologique et évolutive. Collection Ecologie no. 27. Masson, Paris, France.

Blondel, J., C. Ferry, and B. Frochot. 1970. La méthode des indices ponctuels d'abondance (I. P. A.) ou des relevés d'avifaune par stations d'écoute». Alauda38:55-71.

Blondel, J., C. Ferry, and B. Frochot. 1981. Point counts with unlimited distance. Studies in Avian Biology 6:414420.

Borcard, D., P. Legendre, and P. Drapeau. 1992. Partialling out the spatial component of ecological variation. Ecology 73:1045-1055.

Bradshaw, R., P. Gemmel, and L. Björkman. 1994. Development of nature based silvicultural models in southern Sweden: the scientific background. Forest Landscape Research 1:95-110.

Brown, J. H., and A. Kodric-Brown. 1977. Turnover rate in insular biogeography: effects of immigration on extinction. Ecology 58:445-449.

Cameron, H. 1953. Melting point of bounding material in lodgepole and jack pine cone. Silvicultural leaflet 86 . Department of Northern Affairs and Natural Resources, Ottawa, Canada.

Carleton, T. J., and P. McLellan. 1994. Woody vegetation responses to fire versus clear-cutting logging: A comparative survey in the central Canadian boreal forest. Ecoscience 1:141-152.

Cramer, W., and H. Hytteborn. 1987. The separation of fluctuation and long-term change in vegetation dynamics of a rising seashore. Vegetatio 69:157-167.

Cumming, S. G., P. J. Burton, S. Prahacs, and M. R. Garland. 1994. Potential conflicts between timber supply and habitat protection in the boreal mixed-wood of Alberta, Canada: a simulation study. Forest Ecology and Management 68: 281-302.

Dansereau, P.-R., and Y. Bergeron. 1993. Fire history in the southern boreal forest of northwestern Quebec. Canadian Journal of Forest Research 23:25-32.

Darveau, M., L. Bélanger, J. Huot, E. Mélancon, and S. DeBellefeuille. 1997. Forestry practices and the risk of bird nest predation in a boreal coniferous forest. Ecological Applications 7:572-580.

Dobkin, D. S. 1994. Conservation and management of neotropical migrant landbirds in the Northern Rockies and Great Plains. University of Idaho Press, Moscow, Idaho, USA.

Donovan, T. M., P. W. Jones, E. M. Annand, and F. R. Thompson III. 1997. Variation in local-scale edge effects: mechanisms and landscape context. Ecology 78:2064-2075.

Drapeau, P., A. Leduc, and R. McNeil. 1999. Refining the use of point counts at the scale of individual points in 
studies of bird-habitat relationships. Journal of Avian Biology 30:367-382.

Eastman, J. R. 1992. IDRISI version 4. 0. Clark University, Graduate School of Geography, Worchester, Massachusetts, USA.

Edenius, L., and J. Elmberg. 1996. Landscape level effects of modern forestry on bird communities in North Swedish boreal forests. Landscape Ecology 11:325-338.

Eilerstsen, O., O. R. Rune, O. Tonje, and P. Oddvar. 1990. Data manipulation and gradient length estimation in DCA ordination. Journal of Vegetation Science 1:261-270.

Enoksson, B., P. Anglestam, and K. Larsson. 1995. Deciduous forest and resident birds: the problem of fragmentation within coniferous forest landscape. Landscape Ecology 10: 267-275.

Evans, W. G. 1964. Infra-red receptors in Melanophila acuminata DeGeer. Nature 202:211.

Evans, W. G. 1966. Perception of infra-red radiation from forest fires by Melanophila acuminata DeGeer (Coleoptera: Buprestidae). Ecology 47:1061-1065.

Findlay, C. S., and J. Houlahan. 1997. Anthropogenic correlates of species richness in southeastern Ontario wetlands. Conservation Biology 11:1000-1009.

Fowells, H. R. 1965. Silvics of the forest trees of the United States. Agricultural Handbook number 271. U. S. Forestry Service, Washington, D.C., USA.

Franklin, J. F., and R. T. Forman. 1987. Creating landscape patterns by forest cutting: ecological consequences and principles. Landscape Ecology 1:5-18.

Freedman, B., S. Woodley, and J. Loo. 1994. Forestry practices and biodiversity, with particular reference to the Maritime Provinces of eastern Canada. Environmental Review 2:33-77.

Freemark, K. E., J. B. Dunning, S. J. Hejl, and J. R. Probst. 1995. A landscape ecology perspective for research, conservation, and management. Pages 381-421 in T. E. Martin and D. M. Finch, editors. Ecology and management of Neotropical migratory birds, a synthesis and review of critical issues. Oxford University Press, New York, New York, USA.

Freemark, K. E., and H. G. Merriam. 1986. Importance of area and habitat heterogeneity to bird assemblages in temperate forest fragments. Biological Conservation 36:115-141.

Galindo-Leal, C., and F. L. Bunnell. 1995. Ecosystem management: implications and opportunities of a new paradigm. Forestry Chronicle 71:601-606.

Galipeau, C., D. D. Kneeshaw, and Y. Bergeron. 1997. White spruce and balsam fir colonization of a site in the south eastern boreal forest as observed 68 years after fire. Canadian Journal of Forest Research 27:139-147.

Gauthier, S., A. Leduc, and Y. Bergeron. 1996. Forest dynamics modeling under natural fire cycles: a tool to define natural mosaic diversity for forest management. Environmental Monitoring and Assessment 39:417-434.

Gutzwiller, K. J., and S. T. Anderson. 1987. Multiscale associations between cavity-nesting birds and features of Wyoming streamside woodlands. Condor 89:534-548.

Hagan, J. M., and D. W. Johnston. 1992. Ecology and conservation of neotropical migrant landbirds. Smithsonian Institution Press, Washington, D.C., USA.

Hagan, J. M., P. S. McKinley, A. L. Meehan, and S. L. Grove. 1997. Diversity and abundance of landbirds in a northeastern industrial forest. Journal of Wildlife Management 61:718-735.

Haila, Y. 1994. Preserving ecological diversity in boreal forests: ecological background, research, and management. Annales Zoologici Fennici 31:203-217.

Haila, Y., I. K. Hanski, J. Niemelä, P. Punttila, S. Raivio, and H. Tukia. 1994. Forestry and the boreal fauna: matching management with natural forest dynamics. Annales Zoologici Fennici 31:187-202.
Hannon, S. J. 1993. Nest predation and forest bird communities in fragmented aspen forests in Alberta. Pages 127136 in D. H. Kuhnke, editor. Birds in the boreal forest: proceedings of a workshop held March 10-12, 1992, in Prince Albert, Saskatchewan. Northern Forestry Center, Forestry Canada, Northwest Region. Edmonton, Alberta, Canada.

Hansen, A. J., T. A. Spies, F. J. Swanson, and J. L. Ohmann. 1991. Conserving biodiversity in managed forests, lessons from natural forests. BioScience 41:382-392.

Harvey, B. D., and Y. Bergeron. 1989. Site patterns of natural regeneration following clear-cutting in northwestern Quebec. Canadian Journal of Forest Research 19:1458-1469.

Hejl, S. J. 1992. The importance of landscape patterns to bird diversity: a perspective from the Northern Rocky Mountains. Northwest Environment Journal 8:119-137.

Hejl, S. J., R. L. Hutto, C. R. Preston, and D. M. Finch. 1995. Effects of silvicultural treatments in the Rocky Mountains. Pages 220-244 in T. E. Martin and D. M. Finch, editors. Ecology and management of Neotropical migratory birds, a synthesis and review of critical issues. Oxford University Press, New York, New York, USA.

Helle, P., and O. Järvinen. 1986. Population trends of North Finnish land birds in relation to their habitat selection and changes in forest structure. Oikos 46:107-115.

Heltshe, J. F., and N. E. Forrester. 1983. Estimating species richness using the jacknife procedure. Biometrics 39:1-11.

Hill, M. O. 1979. DECORANA-FORTRAN program for detrended correspondence analysis and reciprocal averaging. Cornell University, Ithaca, New York, USA.

Hunter, M. L., Jr. 1990. Wildlife, forests, and forestry: principles of managing forests for biological diversity. Prentice-Hall, Englewood Cliffs, New Jersey, USA.

Hunter, M. L., Jr. 1992. Paleoecology, landscape ecology, and conservation of Neotropical migrant passerines in boreal forests. Pages 511-523 in J. M. Hagan III and D. W. Johnston, editors. Ecology and conservation of Neotropical migrant landbirds. Smithsonian Institution Press, Washington, D.C., USA.

Hutto, R. L. 1995. Composition of bird communities following stand-replacement fires in Northern Rocky Mountain (USA) conifer forests. Conservation Biology 9:1041-1058.

Johnson, E. A. 1992. Fire and vegetation dynamics: studies from the North American boreal forests. Cambridge studies in ecology. Cambridge University Press, Cambridge, UK.

Legendre, L., and P. Legendre. 1983. Numerical ecology. Developments in environmental modelling. 3. Elsevier, Amsterdam, The Netherlands.

Lemhkuhl, J. F., L. F. Ruggiero, and P. A. Hall. 1991. Landscape-scale patterns of forest fragmentation and wildlife richness and abundance in the southern Washington Cascade Range. Pages 425-442 in L. F. Ruggiero, K. B. Aubry, A. B. Carey, and M. H. Huff, editors. Wildlife and vegetation of unmanaged Douglas-fir forests. United States Forest Service General Technical Report PNW-285.

McGarigal, K., and B. J. Marks. 1995. FRAGSTATS-Spatial pattern analysis program for quantifying landscape structure. U.S. Forest Service Technical Report PNW 351.

McGarigal, K., and W. C. McComb. 1995. Relationships between landscape structure and breeding birds in the Oregon coast range. Ecological Monographs 65:235-260.

Noss, R. F. 1993. A conservation plan for the Oregon Coast Range: some preliminary suggestions. Natural Areas Journal 13:276-290.

Paton, P. W. 1994. The effect of edge on avian nest success: how strong is the evidence? Conservation Biology 8:17-26.

Pearson, S. M. 1993. The spatial extent and relative influence of landscape-level factors on wintering bird populations. Landscape Ecology 8:3-18.

Peterjohn, B. G., J. R. Sauer, and C. S. Robbins. 1995. Pop- 
ulation trends from the North American breeding bird survey. Pages 3-39 in T. E. Martin and D. M. Finch, editors. Ecology and management of Neotropical migratory birds, a synthesis and review of critical issues. Oxford University Press, New York, New York, USA.

Quinn, J. F., and A. E. Dunham. 1983. On hypothesis testing in ecology and evolution. American Naturalist 122:602-617.

Ralph, C. J., J. R. Sauer, and S. Droege, editors. 1995. Monitoring bird populations by point counts. General Technical Report PSW-GTR-149. Pacific Southwest Research Station, Forest Service, U.S. Department of Agriculture, Albany, California, USA.

Raphael, M. G., K. V. Rosenberg, and B. G. Marcot. 1988. Large-scale changes in bird populations of Douglas-fir forests, Northwest California. Pages 63-83 in J. A. Jackson, editor. Bird conservation 3. University of Wisconsin Press, Madison, Wisconsin, USA.

Ripple, W. J., G. A. Bradshaw, and T. A. Spies. 1991. Measuring forest landscape patterns in the Cascade range of Oregon, USA. Biological Conservation 57:73-88.

Robbins, C. S., D. K. Dawson, and B. A. Dowell. 1989a. Habitat area requirements of breeding forest birds of the middle Atlantic states. Wildlife Monographs 103:1-34.

Robbins, C. S., J. R. Sauer, R. S. Greenberg, and S. Droege. 1989b. Population declines in North American birds that migrate to the Neotropics. Proceedings of the National Academy of Sciences USA 86:7658-7662.

Robinson, S. K., F. R. Thompson, T. M. Donovan, D. R. Whitehead, and J. Faaborg. 1995. Regional forest fragmentation and the nesting success of migratory birds. Science 267:1987-1990.

Rosenberg, K. V., and M. G. Raphael. 1986. Effects of forest fragmentation on vertebrates in Douglas-fir forests. Pages 263-272 in J. Verner, M. L. Morisson, and C. J. Ralph, editors. Wildlife 2000: modeling habitat relationships of terrestrial vertebrates. University of Wisconsin Press, Madison, Wisconsin, USA.

Rowe, J. S. 1972. Forest regions of Canada. Environment Canada, Ottawa, Canada.

Rudnicky, T. C., and M. L. Hunter Jr. 1993a. Reversing the fragmentation perspective: effects of clearcut size on bird species richness in Maine. Ecological Applications 3:357-366.

Rudnicky, T. C., and M. L. Hunter Jr. 1993b. Avian nest predation in clearcuts, forests, and edges in a forest-dominated landscape. Journal of Wildlife Management 57:358-364.

Ruggiero, L. F., K. B. Aubry, A. B. Carey, and M. H. Huff, technical coordinators. 1991. Wildlife and vegetation of unmanaged Douglas-fir forests. U.S. Forest Service Pacific Northwest Research Station General Technical Report PNW-GTR-285.

SAS 1988. SAS user's guide: statistics. Sixth edition. SAS Institute, Cary, North Carolina, USA.

Schmiegelow, F. K. A., C. S. Machtans, and S. J. Hannon. 1997. Are boreal birds resilient to forest fragmentation? An experimental study of short-term community responses. Ecology 78:1914-1932.

Spies, T. A., and S. P. Cline. 1988. Coarse woody debris in manipulated and unmanipulated coastal Oregon forests. Pages 5-24 in C. Maser, R. F. Tarrant, J. M. Trappe, and J. F. Franklin, editors. From the forest to the ocean - atory of fallen trees. U.S. Forest Service General Technical Report PNW-229.

Spies, T. A., W. J. Ripple, and G. A. Bradshaw. 1994. Dynamics and pattern of a managed coniferous forest landscape in Oregon. Ecological Applications 4:555-568.

Sokal, R. R., and F. J. Rohlf. 1981. Biometry. Second edition. Freeman, San Francisco, California, USA.

Swenson, J. E., and P. Anglestam. 1993. Habitat separation by sympatric forest grouse in Fennoscandia in relation to boreal forest succession. Canadian Journal of Zoology 71: 1303-1310.

Temple, S. A. 1986. Predicting impacts of habitat fragmentation on forest birds: a comparison of two models. Pages 301-304 in J. Verner, M. L. Morisson, and C. J. Ralph, editors. Wildlife 2000: modeling habitat relationships of terrestrial vertebrates. University of Wisconsin Press, Madison, Wisconsin, USA.

Temple, S. A., and J. R. Cary. 1988. Modeling dynamics of habitat-interior bird populations in fragmented landscapes. Conservation Biology 4:340-347.

ter Braak, C. J. F. 1986. Canonical correspondence analysis: a new eigenvector technique for multivariate direct gradient analysis. Ecology 67:1167-1179.

ter Braak, C. J. F. 1988. Partial canonical correspondence analysis. Pages 551-558 in R. H. G. Jongman, C. J. F. ter Braak, and O. F. R. Van Tongeren, editors. Data analysis in community and landscape ecology. Pudoc, Wageningen, The Netherlands.

ter Braak, C. J. F. 1990. Update notes. CANOCO version 3.1. Agricultural Mathematics Group. Wageningen, The Netherlands.

Thompson, F. R., III., W. D. Dijak, T. G. Kulowiec, and D. A. Hamilton. 1992. Breeding bird populations in Missouri Ozark forests with and without clearcutting. Journal of Wildlife Management 56:23-30.

Thompson, F. R., III., G. R. Probst, and M. G. Raphael. 1995. Impacts of silviculture: overview and management recommendations. Pages 201-219 in T. E. Martin and D. M. Finch, editors. Ecology and management of Neotropical migratory birds, a synthesis and review of critical issues. Oxford University Press, New York, New York, USA.

Väisänen, R. A., O. Järvinen, and P. Rauhala. 1986. How are extensive, human-caused habitat alterations expressed on the scale of local bird populations in boreal forests? Ornis Scandinavica 17:282-292.

Van Wagner, C. E. 1978. Age-class distribution and the forest fire cycle. Canadian Journal of Forestry Research 8:431-460.

Vincent, J. L., and L. Hardy. 1977. L'évolution et l'extinction des grands lacs glaciaires Barlow et Ojibway en territoire québécois. Géographie Physique et Quaternaire 31:357-372.

Wallin, D. O., F. J. Swanson, and B. Marks. 1994. Landscape pattern response to changes in pattern generation rules: land-use legacies in forestry. Ecological Applications 4: 569-580.

Welsh, D. A. 1987. The influence of forest harvesting on mixed coniferous-deciduous boreal bird communities in Ontario, Canada. Acta Oecologica 8:247-252.

Welsh, D. A., and L. A. Venier. 1996. Binoculars and satellites: developing a conservation framework for boreal forest wildlife at varying scales. Forest Ecology and Management 85:53-65.

Whitcomb, R. F., C. S. Robbins, J. F. Lynch, B. L. Whitcomb, M. K. Klimkiewicz, and D. Bystrak. 1981. Effects of forest fragmentation on avifauna of the eastern deciduous forest. Pages 125-206 in R. L. Burgess and D. M. Sharpe, editors. Forest island dynamics in man-dominated landscapes. Springer Verlag, New York, New York, USA.

Whittaker, J. 1984. Model interpretation from the additive elements of the likelihood function. Applied Statistics 33: $52-64$.

Wiens, J. A. 1989. The ecology of bird communities. Volumes 1 and 2. Cambridge studies in ecology. Cambridge University Press, Cambridge, UK.

Wiens, J. A. 1994. Habitat fragmentation: island vs. landscape perspectives on bird conservation. Ibis 137:97-104.

Wiens, J. A., N. C. Stenseth, B. Van Horne, and R. A. Ims. 1993. Ecological mechanisms and landscape ecology. Oikos 66:369-380. 


\section{APPENDIX}

Frequency of occurrence of forest bird species in the 459 stations sampled in 1994-1995 in three landscapes of a boreal mixed-wood forest in Abitibi, Quebec. Species are listed from most to least frequent.

\begin{tabular}{|c|c|c|c|c|c|c|c|c|c|c|c|}
\hline \multirow[b]{2}{*}{ Common name } & \multirow[b]{2}{*}{ Scientific name } & \multirow[b]{2}{*}{ Status $\dagger$} & \multirow{2}{*}{$\begin{array}{r}\text { Habita } \\
\text { use } \$\end{array}$} & \multicolumn{2}{|c|}{$\begin{array}{c}\text { Pre-industrial } \\
\quad(n=164) \\
\end{array}$} & \multicolumn{2}{|c|}{$\begin{array}{l}\text { Industrial } \\
(n=169)\end{array}$} & \multicolumn{2}{|c|}{$\begin{array}{c}\text { Natural } \\
(n=126)\end{array}$} & \multicolumn{2}{|c|}{$\begin{array}{l}\text { Study area } \\
(n=459)\end{array}$} \\
\hline & & & & Occur. & $\%$ & Occur. & $\%$ & Occur. & $\%$ & Occur. & $\%$ \\
\hline $\begin{array}{l}\text { White-throated Spar- } \\
\text { row }\end{array}$ & Zonotrichia albicolis & $\mathrm{SD}$ & GEN & 154 & 93.9 & 161 & 95.3 & 114 & 90.5 & 429 & 93.5 \\
\hline Nashville Warbler & Vermivora ruficapilla & NTM & YOF & 143 & 87.2 & 151 & 89.4 & 83 & 65.9 & 377 & 82.1 \\
\hline Red-eyed Vireo & Vireo olivaceus & NTM & GEN & 124 & 75.6 & 122 & 72.2 & 100 & 79.4 & 346 & 75.4 \\
\hline American Redstart & Setophaga ruticilla & NTM & GEN & 134 & 81.7 & 106 & 62.8 & 102 & 81.0 & 342 & 74.5 \\
\hline Swainson's Thrush & Catharus ustulatus & NTM & MAF & 95 & 57.9 & 129 & 76.3 & 115 & 91.3 & 339 & 73.9 \\
\hline Winter Wren & Troglodytes troglodytes & SD & MAF & 74 & 45.1 & 134 & 79.3 & 114 & 90.5 & 322 & 70.2 \\
\hline Hermit Thrush & Catharus guttatus & $\mathrm{SD}$ & YOF & 124 & 75.6 & 128 & 75.7 & 68 & 54.0 & 320 & 69.7 \\
\hline Ovenbird & Seiurus aurocapillus & NTM & MAF & 127 & 77.4 & 80 & 47.3 & 97 & 77.0 & 304 & 66.2 \\
\hline Magnolia Warbler & Dendroica magnolia & NTM & GEN & 73 & 44.5 & 111 & 65.7 & 84 & 66.7 & 268 & 58.4 \\
\hline $\begin{array}{l}\text { Black-and-white } \\
\text { Warbler }\end{array}$ & Mniotilta varia & NTM & GEN & 105 & 64.0 & 89 & 52.7 & 66 & 52.4 & 260 & 56.6 \\
\hline Philadelphia Vireo & Vireo philadelphicus & $\mathrm{SD}$ & YOF & 105 & 64.0 & 76 & 45.0 & 79 & 62.7 & 260 & 56.6 \\
\hline American Robin & Turdus migratorius & $\mathrm{SD}$ & SHR & 126 & 76.8 & 94 & 55.6 & 35 & 27.8 & 255 & 55.6 \\
\hline Ruby-crowned Kinglet & Regulus calendula & SD & MAF & 70 & 42.7 & 99 & 58.6 & 80 & 63.5 & 249 & 54.2 \\
\hline $\begin{array}{l}\text { Yellow-bellied Sap- } \\
\text { sucker }\end{array}$ & Shpyrapicus varius & $\mathrm{SD}$ & MAF & 56 & 34.1 & 113 & 66.9 & 79 & 62.7 & 248 & 54.0 \\
\hline Veery & Catharus fuscescens & NTM & YOF & 114 & 69.5 & 74 & 43.8 & 30 & 23.8 & 218 & 47.5 \\
\hline $\begin{array}{l}\text { Yellow-rumped } \\
\text { Warbler }\end{array}$ & Dendroica coronata & $\mathrm{SD}$ & MAF & 68 & 41.5 & 79 & 46.7 & 71 & 56.3 & 218 & 47.5 \\
\hline Common Raven & 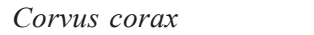 & RES & GEN & 95 & 57.9 & 79 & 46.7 & 43 & 34.1 & 217 & 47.3 \\
\hline Cedar Waxwing & Bombycilla cedrorum & $\mathrm{SD}$ & YOF & 99 & 60.4 & 74 & 43.8 & 37 & 29.4 & 210 & 45.8 \\
\hline Mourning Warbler & Oporornis philadelphia & NTM & YOF & 93 & 56.7 & 84 & 49.7 & 31 & 24.6 & 208 & 45.3 \\
\hline $\begin{array}{l}\text { Golden-crowned King- } \\
\text { let }\end{array}$ & Regulus satrapa & $\mathrm{SD}$ & MAF & 41 & 25.0 & 66 & 39.0 & 84 & 66.7 & 191 & 41.6 \\
\hline $\begin{array}{l}\text { Black-capped Chicka- } \\
\text { dee }\end{array}$ & Parus atricapillus & RES & GEN & 80 & 488 & 57 & 33.7 & 48 & 38.1 & 185 & 40.3 \\
\hline $\begin{array}{l}\text { Yellow-bellied Fly- } \\
\text { catcher }\end{array}$ & Empidonax flaviventris & NTM & GEN & 55 & 33.5 & 79 & 46.7 & 39 & 31.0 & 173 & 37.7 \\
\hline Americ & Corvus & $\mathrm{SD}$ & GEN & 90 & 54.9 & 39 & 23.1 & 25 & 19.8 & 154 & 33.6 \\
\hline Com & Colapt & SD & YOF & 54 & 33.0 & 75 & 44.4 & 25 & 19.8 & 154 & 33.6 \\
\hline wthroat & Geothly & NTM & SHR & 64 & 39.0 & 73 & 43.2 & 10 & 7.9 & 147 & 32.0 \\
\hline Ald & Empido & NTM & SHR & 68 & 41.5 & 74 & 43.8 & 3 & 2.4 & 145 & 31.6 \\
\hline Che & Dendro & NTM & YOF & 47 & 28.7 & 72 & 42.6 & 21 & 16.7 & 140 & 30.5 \\
\hline Red & Sitta canadensis & RES & MAF & 26 & 15.9 & 47 & 27.8 & 64 & 50.8 & 137 & 29.8 \\
\hline Pin & Cardue & & $\mathrm{EN}$ & 50 & 30.5 & 52 & 30.8 & 33 & 26.2 & 135 & 29.4 \\
\hline Blackburnian Warbler & Der & NTM & MAF & 20 & 12.2 & 27 & 16.0 & 73 & 57.9 & 120 & 26.1 \\
\hline Evening Grosbea & $\begin{array}{l}\text { Coccothraustes vesper- } \\
\text { tinus }\end{array}$ & RES & MAF & 30 & 18.3 & 39 & 23.1 & 49 & 38.9 & 118 & 25.7 \\
\hline Gan & a canadensis & & $\mathrm{F}$ & 22 & 13 & 36 & 2 & 54 & 42 & 112 & 24.4 \\
\hline Lea & Empidonc & & $\mathrm{F}$ & 60 & & 31 & 18 & 20 & 15.9 & 11 & 24.2 \\
\hline $\mathrm{Am}$ & $C$ & & $\mathrm{~F}$ & 3 & 1 & 37 & 2 & 4 & 3.2 & 73 & 15.9 \\
\hline Dar & alis & & $\mathrm{F}$ & 1 & 8.5 & 32 & $1 \varepsilon$ & 23 & 18.3 & 69 & 15.0 \\
\hline Ruf & Bo & $S$ & $\mathrm{iN}$ & 52 & 31.7 & 35 & 20.7 & 18 & 14.3 & 105 & 22.9 \\
\hline $\begin{array}{l}\text { Black-throated Green } \\
\text { Warbler }\end{array}$ & Dendroica virens & NT & MAF & 16 & 9.8 & 34 & 20.1 & 51 & 40.5 & 101 & 22.0 \\
\hline Blue & & & $\mathrm{OF}$ & 2 & . & 43 & 25.4 & 32 & 25.4 & 100 & 21.8 \\
\hline $\begin{array}{l}\text { Black-throated Blue } \\
\text { Warbler }\end{array}$ & Dendroica caerulescens & NTM & MAF & 18 & & 22 & 13.0 & 57 & 45.2 & 97 & 21.1 \\
\hline Warbler & 年 & $1 \mathrm{NI}$ & IEN & 58 & 35.4 & 31 & 18.3 & 5 & 4.0 & 94 & 20.5 \\
\hline $\begin{array}{l}\text { White-winged Cross- } \\
\text { bill }\end{array}$ & Loxia leucoptera & RES & MAF & 28 & 17.1 & 41 & 24.3 & 18 & 14.3 & 87 & 19.0 \\
\hline Bay-breasted Warbler & tanea & TM & & 18 & 11.0 & 22 & 13.0 & 44 & 34.9 & 84 & 18.3 \\
\hline Wilson's Warbler & Wilsonia pusilla & NTM & SHR & 33 & 20.1 & 44 & 26.0 & 6 & 4.8 & 83 & 18.0 \\
\hline Purple Finch & Carpodacus purpureus & $\mathrm{SD}$ & MAF & 42 & 25.6 & 16 & 9.5 & 22 & 17.5 & 80 & 17.4 \\
\hline Lincoln Sparrow & Melospiza lincolnii & NTM & SHR & 37 & 22.6 & 40 & 23.7 & 0 & 0.0 & 77 & 16.8 \\
\hline Northern Waterthrush & Seiurus noveboracensis & NTM & MAF & 14 & 8.5 & 19 & 11.2 & 34 & 27.0 & 67 & 14.6 \\
\hline Gray Jay & Perisoreus canadensis & RES & MAF & 9 & 5.5 & 32 & 18.9 & 21 & 16.7 & 62 & 13.5 \\
\hline Brown Creeper & Certhia americana & $\mathrm{SD}$ & MAF & 10 & 6.1 & 19 & 11.2 & 28 & 22.2 & 57 & 12.4 \\
\hline $\begin{array}{l}\text { Rose-breasted Gros- } \\
\text { beak }\end{array}$ & Pheucticus ludovicianus & NTM & YOF & 23 & 14.0 & 16 & 9.5 & 13 & 10.3 & 52 & 11.3 \\
\hline Swamp Sparrow & Melospiza georgiana & $\mathrm{SD}$ & गПк & 24 & 14.6 & 12 & 7.1 & 4 & 3.2 & 40 & 8.7 \\
\hline Common Grackle & Quiscalus quiscula & $\mathrm{SD}$ & SHR & 14 & 8.5 & 16 & 9.5 & 10 & 7.9 & 40 & 8.7 \\
\hline Chipping Sparrow & Spizella passerina & $\mathrm{SD}$ & YOF & 20 & 12.2 & 15 & 8.9 & 2 & 1.6 & 37 & 8.1 \\
\hline Song Sparrow & Melospiza melodia & $\mathrm{SD}$ & YOF & 13 & 7.9 & 14 & 8.3 & 1 & 0.8 & 28 & 6.1 \\
\hline Tree Swallow & Tachycineta bicolor & SD & SHR & 14 & 8.5 & 9 & 5.3 & 4 & 3.2 & 27 & 5.9 \\
\hline
\end{tabular}


APPENDIX. Continued.

\begin{tabular}{|c|c|c|c|c|c|c|c|c|c|c|c|}
\hline \multirow[b]{2}{*}{ Common name } & \multirow[b]{2}{*}{ Scientific name } & \multirow[b]{2}{*}{ Status $\dagger$} & \multirow{2}{*}{$\begin{array}{c}\text { Habitat } \\
\text { use } \\
\end{array}$} & \multicolumn{2}{|c|}{$\begin{array}{l}\text { Pre-industrial } \\
\quad(n=164)\end{array}$} & \multicolumn{2}{|c|}{$\begin{array}{l}\text { Industrial } \\
(n=169)\end{array}$} & \multicolumn{2}{|c|}{$\begin{array}{c}\text { Natural } \\
(n=126)\end{array}$} & \multicolumn{2}{|c|}{$\begin{array}{l}\text { Study area } \\
(n=459)\end{array}$} \\
\hline & & & & Occur. & $\%$ & Occur. & $\%$ & Occur. & $\%$ & Occur. & $\%$ \\
\hline Solitary Vireo & Vireo solitarius & NTM & MAF & 6 & 3.7 & 11 & 6.5 & 10 & 7.9 & 27 & 5.9 \\
\hline Yellow Warbler & Dendroica petechia & NTM & SHR & 16 & 9.8 & 7 & 4.1 & 2 & 1.6 & 25 & 5.4 \\
\hline Downy Woodpecker & Picoides pubescens & RES & YOF & 8 & 4.9 & 6 & 3.5 & 6 & 4.8 & 20 & 4.4 \\
\hline Cape May Warbler & Dendroica tigrina & NTM & MAF & 4 & 2.4 & 6 & 3.5 & 7 & 5.6 & 17 & 3.7 \\
\hline Red-winged Blackbird & Agelaius phoeniceus & $\mathrm{SD}$ & SHR & 6 & 3.7 & 10 & 5.9 & 0 & 0.0 & 16 & 3.5 \\
\hline Hairy Woodpecker & Picoides villosus & RES & MAF & 6 & 3.7 & 4 & 2.4 & 5 & 4.0 & 15 & 3.3 \\
\hline Pileated Woodpecker & Dryocopus pileatus & RES & MAF & 2 & 1.2 & 3 & 1.8 & 10 & 7.9 & 15 & 3.3 \\
\hline Pine Grosbeak & Pinicola enucleator & RES & MAF & 1 & 0.6 & 7 & 4.1 & 6 & 4.8 & 14 & 3.0 \\
\hline Boreal Chickadee & Parus hudsonicus & RES & MAF & 3 & 1.8 & 6 & 3.5 & 0 & 0.0 & 9 & 2.0 \\
\hline Northern Parula & Parula americana & NTM & MAF & 0 & 0.0 & 4 & 2.4 & 4 & 3.2 & 8 & 1.7 \\
\hline Rusty Blackbird & Euphagus carolinus & SD & SHR & 0 & 0.0 & 6 & 3.6 & 0 & 0.0 & 6 & 1.3 \\
\hline $\begin{array}{l}\text { Ruby-throated Hum- } \\
\text { mingbird }\end{array}$ & Archilochus colubris & NTM & YOF & 0 & 0.0 & 3 & 1.8 & 2 & 1.6 & 5 & 1.1 \\
\hline Palm Warbler & Dendroica palmarum & NTM & SHR & 3 & 1.8 & 1 & 0.6 & 0 & 0.0 & 4 & 0.9 \\
\hline American Kestrel & Falco sparverius & SD & SHR & 0 & 0.0 & 4 & 2.4 & 0 & 0.0 & 4 & 0.9 \\
\hline Eastern Kingbird & Tyrannus tyrannus & SD & SHR & 3 & 1.8 & 0 & 0.0 & 0 & 0.0 & 3 & 0.7 \\
\hline Broad-winged Hawk & Buteo platypterus & NTM & YOF & 1 & 0.6 & 1 & 0.6 & 1 & 0.8 & 3 & 0.7 \\
\hline Northern Harrier & Circus cyaneus & SD & SHR & 2 & 1.2 & 1 & 0.6 & 0 & 0.0 & 3 & 0.7 \\
\hline $\begin{array}{l}\text { Black-backed Wood- } \\
\text { pecker }\end{array}$ & Picoides arcticus & RES & MAF & 1 & 0.6 & 1 & 0.6 & 0 & 0.0 & 2 & 0.4 \\
\hline Blackpoll Warbler & Dendroica striata & NTM & MAF & 2 & 1.2 & 0 & 0.0 & 0 & 0.0 & 2 & 0.4 \\
\hline Olive-sided Flycatcher & Contopus borealis & NTM & SHR & 0 & 0.0 & 2 & 1.2 & 0 & 0.0 & 2 & 0.4 \\
\hline Red Crossbill & Loxia curvirostra & RES & MAF & 1 & 0.6 & 1 & 0.6 & 0 & 0.0 & 2 & 0.4 \\
\hline Osprey & Pandion haliaetus & $\mathrm{SD}$ & MAF & 0 & 0.0 & 2 & 1.2 & 0 & 0.0 & 2 & 0.4 \\
\hline Red-tailed Hawk & Buteo jamaicensis & SD & SHR & 0 & 0.0 & 2 & 1.2 & 0 & 0.0 & 2 & 0.4 \\
\hline Eastern Wood-Pewee & Contopus virens & NTM & YOF & 1 & 0.6 & 0 & 0.0 & 0 & 0.0 & 1 & 0.2 \\
\hline Northern Goshawk & Accipiter gentilis & RES & MAF & 1 & 0.6 & 0 & 0.0 & 0 & 0.0 & 1 & 0.2 \\
\hline Brown Thrasher & Toxostoma rufum & $\mathrm{SD}$ & SHR & 1 & 0.6 & 0 & 0.0 & 0 & 0.0 & 1 & 0.2 \\
\hline Great Horned Owl & Bubo virginianus & RES & MAF & 1 & 0.6 & 0 & 0.0 & 0 & 0.0 & 1 & 0.2 \\
\hline Sharp-shinned Hawk & Accipiter striatus & $\mathrm{SD}$ & MAF & 1 & 0.6 & 0 & 0.0 & 0 & 0.0 & 1 & 0.2 \\
\hline Merlin & Falco columbarius & NTM & MAF & 0 & 0.0 & 1 & 0.6 & 0 & 0.0 & 1 & 0.2 \\
\hline Common Nighthawk & Chordeiles minor & NTM & SHR & 0 & 0.0 & 1 & 0.6 & 0 & 0.0 & 1 & 0.2 \\
\hline
\end{tabular}

Note: Species were classified into the following categories: (SHR) early successional habitats, (YOF) young forests, (MAF) mature forests, and (GEN) generalists.

$\dagger$ Species migratory status was based on information contained in Whitcomb et al. (1981), Freemark and Merriam (1986), Robbins et al. (1989a, b), McGarigal and McComb (1995). NTM = Neotropical migrant, SD = Short-distance migrant, RES $=$ Resident.

$\$$ Habitat use is based on empirical patterns of species’ distribution across the gradient of forest types of our study area. 